\title{
Meritocracia à brasileira: o que é desempenho no Brasil?
}

\section{Introdução}

Quando políticos, intelectuais, imprensa e classe média em geral discutem a administração pública no Brasil falam, quase sempre, da necessidade imperiosa de se implantar uma meritocracia no país. Afirmam que falta um sistema que privilegie o mérito e as pessoas que efetivamente trabalham. Os critérios utilizados na avaliação dos funcionários e na concessão das promoções são sempre criticados e vistos como fundamentados em interesses políticos, nepóticos e fisiológicos, que excluem qualquer mensuração de desempenho, eficiência e produtividade. ${ }^{1} \mathrm{O}$ preparo dos avaliadores bem como as metodologias utilizadas também não escapam às críticas.

O interessante acerca desta discussão é o tom de excepcionalidade e novidade em que ela vem envolta, sempre que vem à tona, como se o Brasil fosse um caso especial e a adoção da meritocracia nos colocasse no primeiro mundo. Duas perguntas cabem, de imediato. Primeiro: será que se justifica o caráter de novidade e modernidade, que quase sempre acompanha as discussões sobre o estabelecimento de uma meritocracia no serviço público federal brasileiro? Segundo: será que cabe o tom de excepcionalidade, no nosso caso?

A resposta à primeira pergunta é não, se considerarmos a evidência histórica, tanto geral como específica. Sistemas meritocráticos não são uma invenção da modernidade e, no Brasil,

Lívia Barbosa é professora do Departamento de Antropologia da Universidade Federal Fluminense e doutora em Antropologia Social 
desde 1824, é possível registrar a presença de um sistema meritocrático, em termos de formulação jurídica. Portanto, se há mais de um século e meio já existia a iniciativa de se estabelecer entre nós um sistema deste tipo, a questão que me parece mais relevante é: por que essa forma de hierarquização não consegue se reproduzir e, principalmente, encontrar legitimidade na nossa sociedade, considerando-se que, depois daquela data, foram formulados e postos em prática vários planos que procuravam estabelecer uma meritocracia no serviço público brasileiro? ${ }^{2}$

A resposta à segunda questão também é não. Qualquer revisão da bibliografia especializada indicará que a questão da meritocracia e da sua avaliação é polêmica para toda a teoria da administração moderna e envolve uma dimensão política não só no Brasil como em outros países também. A partir dessas constatações, cabe perguntar em que medida um novo plano de avaliação de desempenho - que hoje aparece atrelado à reforma do Estado poderá atingir os resultados almejados? Ou melhor, será que desta vez vamos? Não acredito.

Por que não acredito? Porque estaremos, mais uma vez, tentando resolver por decreto, ou seja, por mecanismos jurídicos e formais, uma problemática que não pode ser resolvida dessa maneira. A questão não é a existência de um sistema de meritocracia no serviço público brasileiro, mas sim a sua legitimidade na prática social. Ou melhor, a transformação deste sistema meritocrático existente no plano formal e no plano do discurso, em uma prática social meritocrática.

Esta transformação, contudo, não surgirá como uma consequiência natural de bons e modernos planos de avaliação de desempenho, porque, na realidade, já tivemos vários deles. Não virá nem de avaliadores treinados e preparados para executá-los, nem da vontade política de um único governo. A questão é, a meu ver, muito mais ampla e não será resolvida, automaticamente, apenas com a reforma do Estado, nem com a introdução de uma nova metodologia de aferição de desempenho. Não creio que avançaremos muito mais para além de onde já nos encontramos, se não for entendida a raiz da diferença entre a existência de sistemas meritocráticos formais e sua legitimidade prática; o que é desempenho e mérito para diferentes grupos da sociedade brasileira; como as diferentes percepções destas categorias culturais se relacionam com outros valores centrais na nossa dinâmica social - como senioridade, lealdade, dedicação e relações pessoais; o que significa, do ponto de vista sociológico, no Brasil, excluir por falta de desempenho e, finalmente, como esses temas se relacionam 
com fluxos culturais mais amplos — estou me referindo às teorias

da moderna administração de recursos humanos e às mudanças nas relações de trabalho em curso no mundo capitalista. Em suma, não creio que avançaremos muito mais se não entendermos o que realmente está sendo dito neste debate cultural pelos diferentes grupos que dele participam.

A partir do que foi dito, creio que a melhor maneira de enriquecermos nossa compreensão sobre este tema é olharmos a questão da meritocracia em um contexto mais amplo, começando por seu tratamento no interior da teoria da administração, passando em seguida a analisá-la em uma perspectiva intercultural e, posteriormente, sob uma ótica histórico-sociológica, no interior da sociedade brasileira. Desta forma, talvez possamos nos confrontar com velhos mitos a seu respeito e vê-la não como mais um fracasso da sociedade brasileira, mas como uma leitura específica de um determinado conjunto de valores que engendra uma dinâmica social que coloca em confronto uma prática não meritocrática e uma representação social da realidade que privilegia princípios de uma sociedade moderna e igualitária.

\section{Meritocracia, avaliação de desempenho e teoria de administração}

Embora o discurso político e o da teoria de administração não deixem transparecer a complexidade do tema, é bom ter-se claro que meritocracia e avaliação de desempenho são temas extremamente polêmicos, não só no Brasil como em outros países, além de serem questões controversas para a teoria de administração moderna, tanto no âmbito do serviço público como no das empresas privadas.

Do ponto de vista histórico, a política de avaliar as pessoas e suas respectivas produções como um procedimento administrativo regular no interior das organizações começa mais ou menos junto com a revolução nas relações de trabalho trazida por Frederik Taylor. Quando, no início da revolução da produtividade trazida pela administração científica, Taylor sugeriu a aplicação de seu método de eficiência à administração de pessoal, ninguém imaginou na época a grande quantidade de problemas que estava surgindo. Uma coisa é medir a eficiência de máquinas e linhas de produção, que podem ser objetivamente medidas. Outra, é julgar, comparar, avaliar e medir 
as produções humanas, que possuem características difíceis de serem objetivamente avaliadas.

Mesmo assim, durante um longo período e ainda hoje em alguns lugares, desempenho ficou associado só à produtividade, à quantidade de trabalho. A filosofia por trás desse tipo de política de avaliação estava assentada em uma visão de mundo estritamente industrial e empresarial que visava identificar quem trabalhava e quem não trabalhava, melhor dizendo, quem produzia e quem não produzia. A partir da década de vinte, com a escola das Relações Humanas e sua ênfase eminentemente humanista, a visão da avaliação de desempenho, como um artifício punitivo e controlador da produção, começa a ser nuançada. A visão do homo economicus, respondendo apenas aos planos de incentivos salariais foi substituída pelo homo socialis, que responde melhor a incentivos sociais e simbólicos. Entretanto, é em um período bem mais recente que a avaliação de desempenho, como uma política importante de recursos humanos, foi incorporada à administração moderna. Ela perde o caráter subjacente punitivo, de identificar quem trabalha e quem não trabalha, e adquire o status de termômetro das necessidades e das realizações das organizações e dos indivíduos. ${ }^{3}$

Segundo esta perspectiva, através da avaliação de desempenho dos funcionários de uma instituição, podemos identificar as áreas nas quais o treinamento se faz necessário, se os critérios de seleção utilizados estão realmente adequados, se estão selecionando as pessoas certas para os lugares certos, que funcionários devem ser remanejados para serem melhor aproveitados etc.

Embora a filosofia sobre a avaliação de desempenho tenha mudado e, na época atual, ela seja concebida como um poderoso instrumento para a orientação e promoção do crescimento pessoal e profissional das pessoas e das empresas, na prática, contudo, ela é uma fonte de atritos, insatisfações e frustrações para aqueles que a concebem e aplicam, bem como para aqueles que são alvo de sua aplicação. E esta constatação é comum e antiga não só no Brasil, como também em outros países, como os Estados Unidos.

As insatisfações e polêmicas atreladas à avaliação de desempenho existem desde a primeira metade deste século. Em 1938, John M. Pfiffner escreveu:

"Não há, provalvelmente, campo que ofereça conflito mais agudo entre a teoria e a prática do que o que diz repeito à apuração do merecimento. A teoria diz que seria excelente apurar o merecimento dos empregados de acordo com o seu valor e desempenho das funções. Com isso concorda a adminstração, assim como os empregados. Mal, porém, se 
tenta pôr a idéia em execução, é ela bloqueada ou a sua eficácia é reduzida por obstáculos quase insuperáveis." ${ }^{4}$

Em 1937, outro especialista norte-americano em recursos humanos, Harvey Walker, afirmava:

"Os sistemas menos eficientes são olhados com desconfiança pelos empregados e, provavelmente, é melhor não ter sistema algum do que ter um que produza resultados nos quais a maioria dos empregados não deposita confiança." ${ }^{5}$

Entretanto, o ataque mais famoso de toda a teoria da administração contra a avaliação de desempenho dos assalariados partiu de Edward Deming, guru norte-americano dos programas de qualidade no Japão, que considera esse processo uma das cinco doenças fatais que atingem a administração. Segundo Deming, o sistema anual de avaliação de desempenho dos assalariados é negativo porque é um sistema arbitrário e injusto, que desmoraliza os empregados, alimenta o desempenho imediatista, aniquila o trabalho em equipe, estimula o medo e a mobilidade administrativa, já que as pessoas mal avaliadas tendem a procurar outros empregos. ${ }^{6}$

Outros teóricos modernos, como Juran e Ishikawa, ligados também aos programas de qualidade, afirmam que se 80 a $85 \%$ dos problemas das empresas são de origem sistêmica e não da responsabilidade individual dos funcionários, como avaliá-los devidamente? Como será possível discernir, em um mau desempenho, a parcela de culpa do sistema e a da responsabilidade do indivíduo??

Entretanto, paralela à visão anterior encontra-se outra, tão antiga quanto a primeira, que vê na avaliação de desempenho uma necessidade fundamental para qualquer administração moderna. Em 1937, Mosher, Kingsley e Stahl afirmavam acerca do assunto:

"Em conclusão, é francamente reconhecido que os sistemas de apuração ou avaliação do merecimento revelaram-se, no passado, acima de tudo, rudimentares e imperfeitos processos de apreciação e registro de aptidões e hábitos de trabalho. Desde, porém, que eles são preferíveis a julgamentos não escritos formulados individualmente pelos administradores, a administração de pessoal deve aceitar o desafio da situação e fazer por desenvolver instrumentos mais adequados e úteis." 
Outra citação de um gerente da mesma época é uma verdadeira profissão de fé acerca da necessidade da avaliação de desempenho:

"Acredito que, praticamente, experimentamos todos os tipos de sistemas de apuração de merecimento que apareceram. Nem um deles se revelou inteiramente satisfatório e qualquer um é, sem sombra de dúvida, melhor do que nada." 9

Se quisermos desconsiderar esta questão, afirmando que a bibliografia é muito antiga, basta verificar que a consideração de novas técnicas de seleção, de avaliação, de treinamento e acompanhamento continua sendo um dos temas mais presentes nos seminários e congressos de administradores, nos artigos de períodicos especializados e nas discussões diárias das organizações. ${ }^{10}$

Para aqueles que defendem a avaliação de desempenho, a questão se reduz a encontrar o melhor método de avaliação. Nesta perspectiva, toda a discussão sobre o assunto torna-se uma discussão formal, de como fazer, e não uma discussão substantiva, sobre se desempenho e mérito podem e devem ser medidos e avaliados e em que consistem. As afirmações de J.B. Probst, embora datadas de 1938, sintetizam todo o dilema que perpassa a administração moderna ainda hoje. ${ }^{11}$

"Apurar ou não o merecimento não é mais a questão. O essencial é como apurar o merecimento - como apurá-lo meticulosamente, facilmente, sem preconceitos e sem levantar antagonismo."

Os argumentos a favor da avaliação de desempenho fundamentam-se em dois tipos de causas: uma de natureza pragmática e outra de cunho psicológico. A primeira afirma que vários outros subsistemas da área de recursos humanos - e não só a avaliação de desempenho - ensejam também distorções como o recrutamento, a seleção, a demissão e a movimentação das pessoas no interior da empresa e nem por isso deixam de ser realizados. E a razão para isso é muito óbvia: toda e qualquer empresa tem que selecionar, encarreirar e excluir pessoas, pois os quadros de uma empresa não são ilimitados nem a inserção é uma decisão voluntária e unilateral. Portanto, a avaliação, como a seleção de pessoas, é uma exigência lógica do próprio sistema econômico administrativo. 
A segunda se baseia em uma visão acerca da constituição da natureza humana, que é bem sintetizada pelas teorias de motivação produzidas nos Estados Unidos por David McClelland, Abraham Maslow, Frederick Herzberg e Victor Vroom. Não cabe resenhá-las aqui uma a uma, mas, de modo geral, estas teorias afirmam que os atos humanos são movidos por ações racionais, motivadas ou impulsionadas por forças interiores, que visam satisfazer alguma necessidade humana básica do tipo: achievement, power, expectativa etc. Negar reconhecimento e espaço para esses impulsos humanos universais é o caminho mais rápido para o desestímulo, a baixa produtividade e a estagnação, pois tira do homem a vontade de crescer e progredir. ${ }^{12}$

Neste contexto, a avaliação de desempenho, e o resultado que dela advém em termos de mobilidade vertical interna nas empresas, funciona como um instrumento fundamental para a satisfação de algumas dessas necessidades, induzindo as pessoas a tentarem obter resultados melhores com vistas a obterem recompensas maiores.

Na prática, os dilemas criados pelos sistemas de avaliação de desempenho têm sido desde o início resolvidos pela teoria de administração e pelos administradores através da atribuição de culpa aos instrumentos utilizados para a avaliação. Ou os sistemas utilizados são vistos como inadequados ou os avaliadores são considerados mal preparados. ${ }^{13}$

O objetivo, então, é encontrar um sistema de avaliação ideal e uma metodologia que consiga, de alguma maneira, neutralizar ou controlar a subjetividade do avaliador. O que se observa, então, é uma crítica permanente ao sistema em uso e a proposta de novos planos que terminam sempre tendo o mesmo destino do que o precedeu.

Essa visão das raízes dos males da avaliação de desempenho baseia-se na suposição da existência de uma realidade concreta e objetiva que pode ser captada em sua dimensão concreta, fotográfica, nos seus mínimos detalhes, e livre da subjetividade do observador, desde que se usem os meios científicos adequados. $\mathrm{O}$ objetivo final é a criação de uma engenharia social que consiga mapear e controlar a realidade tão exatamente como se imagina que ainda possa ocorrer no mundo físico. Embora este seja um pressuposto geral da teoria de administração, existem diferenças (e veremos isso posteriormente) na maneira como as sociedades lidam com essa pressuposição, que refletem o que elas pensam sobre o que é meritocracia e quais os problemas que surgem no momento da sua implementação prática. É nesta dimensão que residem as especificidades dos diversos universos sociais a esse respeito. 
O que é realmente importante para os nossos propósitos é enfatizar que meritocracia e a sua aferição não são uma questão tranqüila para a teoria da administração. Portanto, os descompassos existentes entre nós não são fruto de nenhuma incapacidade nativa de implementação.

\section{Ideologia meritocrática e sistemas meritocráticos}

Seguindo a nossa proposta de analisar as questões da meritocracia e da avaliação de desempenho num contexto mais amplo, é importante perceber que, do ponto de vista intercultural, a polêmica em torno desses temas configura-se hoje em um debate cultural que já extravasou as fronteiras da administração e, junto com a idéia de cultura, é utilizado para explicar ritmos e estilos de desenvolvimento. Por exemplo, o tradicional sistema japonês de senioridade, no qual a posição e o salário de uma pessoa são determinados pelo seu tempo em uma organização — o mérito dos anos - é visto como estando com os dias contados. ${ }^{14}$ Segundo a discussão corrente hoje entre intelectuais, empresários e administradores na sociedade japonesa, para o Japão continuar crescendo, a mobilidade vertical das pessoas no interior das empresas deve ser determinada pelo desempenho delas e não mais pelo tempo de serviço de cada uma. ${ }^{15}$ Pergunta-se: que tensões nascerão deste movimento de um sistema que privilegia a antigüidade para outro que enfatiza o mérito, e como isso será feito em uma sociedade que sempre trabalhou em grupo e capitalizou o mérito individual para o grupo?

Por outro lado, nos Estados Unidos - uma sociedade que, via de regra, sempre funcionou considerando o desempenho e o mérito individual das pessoas como o principal ordenador das hierarquias, mensurando-o da forma a mais objetiva possível discute-se hoje, na era do trabalho em equipe, como estimular essa nova forma de relações de trabalho e, ao mesmo tempo, continuar a reconhecer a contribuição individual. ${ }^{16}$ Portanto, esse não é um dilema tipicamente brasileiro como muitas vezes se faz crer. Além do mais, a sociedade brasileira opera no seu interior com vários e diferentes sistemas meritocráticos. Os concursos públicos, o vestibular, as entrevistas e a avaliação de curriculum utilizados pelas 
grandes empresas privadas e os seus sistemas de promoção estão

todos calcados em uma visão meritocrática.

Um outro aspecto central desta discussão, sistematicamente ignorado, mas que nos permite enfocá-la em uma outra perspectiva, é a evidência histórico-sociológica do dilema que as sociedades complexas, de forma geral, sempre enfrentaram entre escolher o mérito, a antigüidade e o status hereditário na hora de se organizarem social e administrativamente. Mais ainda, o reconhecimento secular de que a capacidade individual é aleatoriamente distribuída entre os diferentes segmentos, sem que isso implique uma concepção igualitária de sociedade.

No Japão Tokugawa este debate é claro. Nishikawa Joken, no início do século XVIII, sugeria que o Japão deveria seguir o exemplo da Índia, onde grande parte das pessoas, com exceção de alguns poucos funcionários designados hereditariamente, permanecia analfabeta e ignorante de qualquer coisa que não fosse a lei a que tinha que obedecer, ao contrário da China, onde os postos na administração pública eram ocupados por funcionários concursados, escolhidos por competência e independentemente da posição social. Aliás, a China Imperial, um antigo modelo para o Japão, em termos culturais, durante séculos, ${ }^{17}$ era uma fonte permanente de referência para esse debate. Ogyu Sorai, um intelectual da época Tokugawa, contrastava o sistema feudal hereditário com o governo centralizado, administrado por funcionários escolhidos por mérito, e afirmava que apenas na China antiga e feudal e no Japão da época em que ele escrevia, podiam ser encontrados governos estáveis e bons. Seus argumentos vão todos na direção de mostrar que o sistema meritocrático ameaçava a ordem social e estimulava a deslealdade dos funcionários, na medida em que, primeiro, o sistema de exames podia fazer com que um homem de posição inferior se saísse melhor do que um superior e, segundo, estimulasse a deslealdade, pois funcionários que se movem de um posto para outro não estão ligados por nenhum laço emocional, nem aos seus superiores, nem aos inferiores. O resultado disso, segundo Sorai, era a necessidade de um rígido sistema de controle e punição para vigiar o comportamento desses funcionários e o estado de suspeição e rebelião que se estabelecia entre eles.

Um século mais tarde, um outro intelectual japonês, Hirose Tanso, alinhavava um argumento dentro dos mesmos parâmetros. Segundo ele, como os funcionários chineses não possuíam nenhuma segurança de serem mantidos no emprego, podendo ser dispensados a qualquer momento e nada sendo garantido a seus filhos, eles se 
preocupavam apenas em usufruir de seus momentos de poder sem nenhuma preocupação com as gerações futuras.

Essas posições não eram unânimes e eram frontalmente contestadas por outros intelectuais da mesma época. Ise Sadatake afirmava que nomear funcionários por nascimento e status é como "botar gatos para amedrontar ladrões e cachorros para caçar ratos". Um outro afirmava que o daimyo (senhor feudal) tendia a escolher como seus subordinados pessoas que lhe eram semelhantes em temperamento e habilidades, aumentando, desmesuradamente, as suas próprias deficiências de caráter. Kamei Nammei assinala, na mesma época, que funcionários apontados por favoritismo não são confiáveis aos olhos de seus superiores. Conseqüentemente, esses superiores interferem constantemente no trabalho dessas pessoas, de forma que os subordinados perdem tanto a autoridade como o incentivo para trabalharem bem.

Mesmo comungando dessas idéias, nenhum dos intelectuais japoneses do período Tokugawa tinha ilusão quanto à possibilidade de o sistema hereditário ser abolido. Por outro lado, os que defendiam o sistema hierárquico de privilégios compartilhavam com os seus oponentes a idéia de que, pelo menos em determinado grau, o princípio básico de um bom governo era promover o mais capaz em detrimento do incapaz. O consenso terminava exatamente onde começava a questão de até quanto se deveria permitir que o mérito suplantasse a hereditariedade e a posição social. ${ }^{18}$

Como podemos ver, tanto a China quanto o Japão são exemplos claros da antigüidade e da natureza estrutural do debate acerca de que critério uma sociedade deve adotar para preencher os seus cargos administrativos e políticos. Ele não veio com a modernidade nem com o sistema econômico capitalista. Mas, podemos perguntar, esta sua natureza estrutural adquire alguma especificidade na época contemporânea e nas sociedades industriais modernas? Certamente que sim. E esta especificidade é dada por uma distinção básica, mas raramente feita entre sistemas meritocráticos e ideologia de meritocracia.

Meritocracia enquanto, critério de ordenação social, é diferente de meritocracia enquanto ideologia. No primeiro caso, o mérito - a capacidade de cada um realizar determinada coisa ou se posicionar em uma determinada hierarquia, baseado nos seus talentos ou esforço pessoal - é invocado como critério de ordenação dos membros de uma sociedade apenas em determinadas circunstâncias. No segundo, ele é o valor globalizante, o critério fundamental e considerado moralmente correto para toda e qualquer 
ordenação social, principalmente no que diz respeito à posição sócio-

econômica das pessoas. Ou seja, num universo social fundado em uma ideologia meritocrática, as únicas hierarquias legítimas e desejáveis são baseadas na seleção dos melhores. Existe, portanto, uma grande diferença entre sistemas sociais meritocráticos apenas para determinados fins e sociedades organizadas a partir de uma ideologia de meritocracia, onde quase toda e qualquer posição social deve ser ocupada pelos melhores com base no desempenho individual.

Desta distinção anterior derivam várias proposições. A primeira é que toda e qualquer sociedade reconhece que seus membros individuais (sujeitos empíricos) diferem entre si em termos dos resultados que apresentam no desempenho de determinadas funções. Esse reconhecimento, contudo, pode ser socialmente legitimado ou não, através do estabelecimento de hierarquias formais específicas, que apenas possuem valor num certo contexto social. Isso significa que o mérito é o valor globalizante apenas para determinados fins, por exemplo para a admissão no serviço público (como era o caso dos mandarins da China Imperial), não implicando a sua utilização para outros domínios, para os quais esses universos sociais lançam mão de atributos pessoais adquiridos por nascimento ou casamento.

A segunda proposição é de que não existe ligação necessária entre sistemas meritocráticos e sociedades complexas e, conseqüentemente, não há relação excludente entre sistemas meritocráticos e sociedades tradicionais e hierárquicas. Os exemplos da China e do Japão falam por si mesmos.

A terceira proposição, derivada da distinção entre sistema meritocrático e ideologia meritocrática, é de que existe uma relação clara entre sociedades modernas, complexas e igualitárias e a vigência de uma ideologia meritocrática. Explico melhor. $O$ fato de uma sociedade hierarquizar seus membros para determinados fins, tomando como base os seus atributos e talentos pessoais, não faz dessa sociedade uma sociedade igualitária. Ou seja, ela não vai considerar sempre os indivíduos como tabula rasa e os diferenciar entre si apenas através dos seus respectivos desempenhos, desconhecendo os atributos adquiridos ou por nascimento ou por status. Em muitas circunstâncias, essas sociedades vão ordenar seus membros justamente por esses atributos, que nada têm a ver com o mérito ou o esforço de cada um. As sociedades hierárquicas podem funcionar como meritocráticas em determinadas circunstâncias, embora não seja essa sua ideologia globalizante. Elas partem do pressuposto de que as pessoas não são iguais em relação 
a um determinado valor que elas tomam como central e globalizante para a ordenação geral da sociedade.

Por outro lado, as sociedades igualitárias têm como princípio básico o fato de que os indivíduos são iguais e que a única coisa a diferenciá-los, para fins de ordenação social, em termos de status, poder econômico e político, é o desempenho de cada um. De acordo com a ideologia prevalecente no interior das sociedades individualistas e modernas, a posição de cada pessoa no interior da estrutura social deve ser determinada pela capacidade individual, por aquilo que cada um é capaz de realizar. Em outros termos, neste tipo de sociedade, o único tipo de hierarquia desejável e legítima é a que classifica as pessoas exclusivamente por seus talentos e capacidades individuais demonstrados no desempenho de determinadas tarefas e funções. Isso significa que as pessoas são comparadas e classificadas tomando-se como base o desempenho relativo de cada uma, e que nenhum outro fator (relações pessoais e consangüíneas, poder econômico e político) pode ser levado em conta nesse processo classificatório, sob pena de invalidar a filosofia central de todo o sistema. A estes são atribuídos reconhecimento público e formal sob a forma de cargos, salários, privilégios, status e prestígio. Além disso, o sistema meritocrático é uma exigência de uma sociedade democrática, que, do ponto de vista dos princípios, garante a igualdade de oportunidades para todos. Na medida em que as nomeações e promoções recaem em indivíduos capazes, de competência reconhecida e comprovada, esse princípio é concretizado, pois as oportunidades estão abertas a todos os que demonstram ter competência e não estão circunscritas às pessoas dotadas de relações pessoais e de parentesco. Em suma, nesta perspectiva, a meritocracia alia igualdade de oportunidades com eficiência.

Se este é o valor central que norteia o processo de estratificação e mobilidade social desses universos sociais, nada mais lógico, portanto, do que se estabelecer processos de avaliação que permitam a formação de hierarquias de desempenho, nas quais as posições mais elevadas devem ser ocupadas por aqueles que, comprovadamente, se desincumbiram de forma melhor de um trabalho ou se sobressaíram em um determinado domínio. Neste sentido, as hierarquias construídas pelas meritocracias são excludentes, pois elas almejam a seleção do melhor ou melhores. Mais ainda, são duplamente excludentes porque, dentre os selecionados como os melhores, escolhem novamente os melhores para liderar os processos e ocupar os lugares no topo da hierarquia. As sociedades individualistas modernas são simultaneamente 
sociedades que operam através de sistemas meritocráticos e têm uma ideologia de meritocracia.

Consequientemente, no contexto destas sociedades, a questão central do debate não é mais qual o critério que deve servir de parâmetro para as hierarquias sociais, pois este já está dado mérito/desempenho - , mas sim uma questão de ordem prática: se todos nós queremos os melhores, como selecioná-los e que instrumentos utilizar para realizar esta seleção?

Tudo que foi dito acima pode parecer muito óbvio e muito simples quando explicitado teoricamente, mas quando nos voltamos para a prática tudo se complica, já que as definições e os critérios sobre o que é desempenho e os fatores que entram na sua contabilização não são unívocos. Lingüisticamente, as categorias mérito e desempenho são as mesmas; entretanto, o conteúdo cultural pode divergir de sociedade para sociedade e no interior da mesma sociedade, gerando interpretações divergentes.

A polêmica em torno da questão da meritocracia e da avaliação de desempenho no Brasil origina-se, justamente, dessa atribuição de conteúdos distintos para uma mesma categoria lingüística por diferentes segmentos sociais e pelo exercício de um discurso que valoriza a meritocracia como critério básico de ordenação social, mas que contrasta, fortemente, com a prática social de todos os segmentos da sociedade brasileira. Ela se encontra permeada por uma total falta de entendimento sobre o que está sendo dito pelos diferentes grupos envolvidos e pela confusão entre sistema meritocrático e ideologia da meritocracia.

Do ponto de vista formal e jurídico, a sociedade brasileira, de um modo geral, e o serviço público, de forma particular, encontram-se, sem dúvida alguma, organizados como um sistema meritocrático, tanto para o ingresso quanto para a mobilidade no seu interior. Entretanto, a leitura da "realidade empírica" pelos diferentes segmentos sociais envolvidos nesse debate - elites políticas, intelectuais e servidores públicos — não ratificam o Brasil como uma sociedade ideologicamente meritocrática. Primeiro, porque outros critérios, como relações pessoais, de parentesco, de posição social e de antigüidade são utilizados, lado a lado com princípios meritocráticos, na colocação das pessoas no interior da nossa estrutura social. E, segundo, porque o significado do que é desempenho e a sua importância relativa aos valores anteriores não é a mesma para todos os grupos. A história da implantação de um sistema meritocrático no serviço público brasileiro é um exemplo do que falei. Além de nos demonstrar a existência desses mútiplos critérios na classificação das pessoas no interior das hierarquias 
administrativas, ela nos sugere, também, os diferentes conteúdos culturais correntes na sociedade do que é mérito e desempenho e que levam pessoas de diferentes segmentos a valorizarem vínculos de natureza diversa - morais e profissionais - com as suas respectivas organizações.

\section{Sistema meritocrático e administração pública brasileira}

\subsection{Ingresso}

A idéia de que o serviço público deva ser estruturado como uma meritocracia é, do ponto de vista histórico, bastante antiga no Brasil, embora a impressão do senso comum é de que esta discussão é recente e moderna. A Constituição de 25 de março de 1824 delineia claramente os fundamentos de uma meritocracia. O artigo 179, item XIV, reza:

"Todo cidadão pode ser admitido aos cargos públicos civis, políticos ou militares, sem outra diferença que não seja por seus talentos ou virtudes."19

Este artigo colocava o acesso aos cargos públicos como uma possibilidade aos indivíduos que tivessem "virtudes e talentos", ou seja, não os tornava bens exclusivos das nomeações nepóticas e políticas. Como o artigo não especificasse o processo de aferição dos referidos "talentos e virtudes", as nomeações ficavam, na prática, ao sabor de quem tivesse o poder de nomear. Esta Constituição, no que dizia respeito à entrada para o serviço público, estabelecia, pela primeira vez no Brasil, a possibilidade de um critério meritocrático, embora não fornecesse instrumentos para orientar a prática social na mesma direção. Salvo algumas exceções, como é o caso da legislação que organizou o Tesouro Público Nacional e as Tesourarias das Províncias - lei de 4 de outubro de 1831 - que, no seu artigo 96, estabelecia alguns critérios para a contratação das pessoas:

"Não se admitirá de ora em diante pessoa alguma, senão por concurso, em que se verifique que o pretendente tem os princípios de gramática da língua nacional e da escrituração por partidas dobradas e cálculo mercantil, unindo a isto boa letra, boa conduta moral e idade de vinte e um anos para 
cima. Os casados em igualdade de circunstâncias serão

preferidos aos solteiros." 20

É importante observar, conforme assinalei anteriormente, quando da distinção entre sistemas e ideologia meritocrática, que essa mesma Constituição de 1824, que colocava o mérito/ desempenho individual como uma possibilidade para a admissão ao serviço público, estabelecia distinções entre os indivíduos no momento da concessão do direito ao voto. Este era um direito de apenas algumas categorias. ${ }^{21}$ No seu interior temos, portanto, tendências inteiramente opostas. O artigo 179 apontava o mérito como um critério de acesso ao serviço público, um outro - o 170 - afirmava a igualdade de todos perante a lei e os artigos 92, 93, 94 e 95 estabeleciam os critérios para o direito ao voto, critérios estes que excluíam do exercício pleno da cidadania pessoas em determinadas posições sociais e níveis de renda. Para alguns fins, essa Constituição apontava para um sistema meritocrático, para outros apontava para uma hierarquização baseada no status e posição econômica. Ela mesclava, do ponto de vista formal e juridico, critérios que hoje se encontram combinados apenas na prática social brasileira.

A primeira Constituição da República - de 24 de fevereiro de 1891 - no seu artigo 73 reafirma o direito de livre acesso de todos os brasileiros aos cargos públicos civis e militares, observadas as condições de capacidade especial exigidas pela lei sendo, porém, vedadas as acumulações remuneradas. Ficou a cargo da lei ordinária dispor sobre os critérios exigidos para a entrada. ${ }^{22}$

A Constituição de 16 de julho de 1934 vai inovar duas vezes. Primeiro, no seus artigo 168, reafirma o direito ao livre acesso de todos os brasileiros aos cargos públicos e inova ao estabelecer que não haveria mais distinções de sexo e estado civil, existentes na legislações anteriores, que asseguravam aos homens casados prioridade na obtenção de um cargo público em relação aos solteiros. Ou seja, estabelece um critério universalizante para o ingresso. Segundo, no artigo 170, disporá que "a primeira investidura nos postos de carreira das repartições administrativas e nos demais que a lei determinar efetuar-se-á depois de exame de sanidade e concursos de provas ou títulos." 23

Com essa disposição, assegura-se o direito universal de acesso ao serviço público a todos os brasileiros, independente de sexo ou estado civil, através de concurso aos seus cargos iniciais, ao mesmo tempo que libera os escalões superiores para as nomeações e influências políticas, tradição que se mantém, em parte, até hoje. Esta tradição, de alocar os cargos mais altos da administração para 
as nomeações políticas, deu origem ao conto de Monteiro Lobato, "Luzeiro Agrícola", de 1928, no qual um poeta fracassado pede emprego público a um chefe político. Este lhe oferece os cargos mais altos e, diante da solicitação do poeta para cargos mais humildes, recebe a resposta: "mas para estes, só com concurso". ${ }^{24}$

As demais constituições — 1937, 1946, 1967, 1969 e 1988 não fazem referência explícita à capacidade individual. Contudo, ao estabelecerem que o critério de admissão ao serviço público deveria ser o concurso aberto a todos os brasileiros, deixam implícita a idéia de que o anonimato e a impessoalidade que, teoricamente, cercam esse procedimento, selecionam pelo mérito pessoal, por ignorarem atributos sociais como status, poder político e econômico, relações consangüíneas e pessoais. ${ }^{25}$

A presença destes dispositivos em todas as constituições não significa, contudo, a consagração definitiva do mérito como sistema prevalecente na admissão para o serviço público. No período que vai de 1934 até os dias atuais, registram-se avanços e recuos na legislação no que concerne à consagração definitiva do concurso público como o único meio de ingresso. Segundo Couto (1966), de acordo com estatísticas da Divisão de Seleção e Aperfeiçoamento do DASP, de 1937 a 1962.

"Inscreveram-se em concurso 695.499 candidatos, dos quais compareceram à primeira prova somente 285.852, logrando habilitação, afinal, apenas 75.1555, o que equivale a pouco mais de $10 \%$ dos inscritos. Destes, é preciso frisar, alguns não chegaram a ser nomeados e outros, por terem conseguido habilitação em vários concursos, o foram mais de uma vez. Atualmente, o Serviço Público Civil conta com aproximadamente 677.000 funcionários, sendo 312.000 da Administração centralizada e 365.000 da descentralizada, dos quais pouco mais de 100.000 ingressaram através de concursos públicos realizados pelo DASP ou por outros órgãos da administração, que dispunham do seu próprio sistema de mérito. Como facilmente se conclui, as cifras estão a evidenciar que, na batalha das leis, tem saído vencedor o regime do pistolão, com uma diferença superior a 500.000 sobre o seu adversário, o sistema de mérito". ${ }^{26}$

Embora, hoje, não tenhamos dados acurados a respeito do serviço público brasileiro que nos permitam fazer cálculo semelhante ao da era do DASP, a evidência empírica sinaliza, contudo, para a manutenção de uma situação semelhante. Se considerarmos que, 
até há bem pouco tempo, existiam, no serviço público brasileiro, inúmeras tabelas especiais que permitiam a contratação de pessoas sem concurso e a prática, bastante comum e sustentada politicamente por vários grupos, de se efetivar os contratados e os chamados trens de alegria das vésperas de fim de mandato - a proporção de não concursados para concursados certamente seria bem maior. ${ }^{27}$

Antes de prosseguirmos, acho importante registrar que, necessariamente, não é a existência ou não de um dispositivo como o concurso que garante que um determinado sistema privilegie o mérito. Existem sistemas meritocráticos que não selecionam os melhores por um concurso e sim pelo desempenho já comprovado em determinadas tarefas ou pela qualificação. Entretanto, no Brasil, e voltarei a esse ponto mais adiante, o concurso é um elemento paradigmático na legitimação de meritocracia. Na realidade, existe no plano das representações na nossa sociedade uma superposição entre instrumentos democráticos, como é o caso do concurso, e sistemas meritocráticos.

\subsection{Mobilidade interna}

Da mesma forma que o ingresso no serviço público brasileiro esta centrado na idéia do mérito de cada um — seja explicitamente, co-mo na Constituição de 1824, seja implicitamente, como nas demais - , via concurso, a mobilidade vertical ou a promoção também é concebida no interior da nossa administração federal como devendo ser o resultado do desempenho de cada um. ${ }^{28}$

A partir da chamada "lei do reajustamento" - lei 284 de 28 de outubro de 1936 - que pode ser considerada o início da administração moderna no serviço público brasileiro — , foi institucionalizado o sistema do mérito através do concurso e foram fixadas as diretrizes do primeiro plano de classificação e de avaliação de desempenho e cargos.

Os últimos sistemas colocados em vigor em 1966, 1977 e 1980 reafirmam a meritocracia como o critério absoluto e condicionam a promoção por antigüidade a um bom desempenho. Ou seja, embora esses planos de avaliação contemplem a progressão por antigüidade, a sua concretização depende, pelo menos no papel, da avaliação de desempenho do funcionário. Por exemplo, o plano de 12 de julho de 1960 , promulgado pela lei $\mathrm{n}^{\mathbf{0}} 3780$, que reestruturava a carreira do servidor público federal, estabelecendo os critérios para a promoção por merecimento e por antigüidade pela metodologia da escala gráfica, estabelece que somente poderá ser promovido por 
antigüidade o funcionário que tiver obtido, pelo menos a metade do máximo atribuível $(50-2=25)$.

"De fato, em se tratando de servidor descumpridor de seus deveres funcionais ou inapto para exercer atividades mais relevantes que as atuais, não deve a Administração premiálo com promoção mesmo que seja o mais antigo na classe." ${ }^{29}(?)$

\section{E continuava :}

“... a rigor, não deveria haver promoções por antigüidade, mas exclusivamente por merecimento. A razão óbvia: o funcionário deve estar comprovadamente apto a desempenhar as tarefas específicas da classe para a qual é promovido. E essa condição fundamental não é satisfeita pela simples circunstância de ser o funcionário mais antigo na classe anterior, mas sim através de criteriosa aferição de sua eficiência funcional e das qualificações exigidas para o desempenho daquelas atribuições..." ${ }^{30}($ ?)

O sistema de 24 de outubro de 1977, promulgado pelo decreto $\mathrm{n}^{\circ} 80.602$, que instituía a avaliação de desempenho no serviço público federal pelo método da distribuição forçada, chegou ao ponto de extinguir a promoção por antigüidade. De acordo com este plano, somente $20 \%$ dos funcionários poderiam receber avaliação MB (muito bom ), 70\% de avaliação B (bom), e 10\% de R (regular).

O sistema atual, seguindo o modelo de 1960, submete, também, a promoção por antigüidade, teoricamente, à avaliação de desempenho. Digo teoricamente porque, na prática, as pessoas são automaticamente promovidas. Por exemplo, no caso dos professores universitários, a cada interstício de 24 meses a pessoa pode ser promovida, caso apresente desempenho para isso. De um modo geral, forma-se uma comissão, em cada departamento, que avalia as atividades desenvolvidas e o desempenho do professor candidato à progressão ao longo desse período. O conteúdo desses relatórios é muito significativo. São relatórios basicamente descritivos das atividades corriqueiras do magistério, do tipo de curso dado, orientação de alunos etc. ... nos quais não há parâmetro que meça ou avalie o que foi realizado. O interessante é que são feitos e exigidos como um fator que condiciona a progressão vertical do professor. Na maioria dos casos, eu arriscaria $99,9 \%$, todos 
são considerados com um bom desempenho das suas funções, o

que transforma esta promoção em um dispositivo automático, e a exigência do relatório, em um dispositivo estritamente burocrático. $O$ resultado desse burocratismo com base na descrição de atividades é que a maioria dos departamentos das universidades federais está congestionada de professores adjuntos IV, encontrando-se nas categorias inferiores apenas os que entraram mais tarde. Depreende-se disso que, para chegar quase ao final da carreira do magistério universitário, basta ficar tempo suficiente no cargo, pois são muito variadas as qualificações dos professores adjuntos IV: professores com mestrado, com doutorado, com especialização ou apenas com graduação e, também, aqueles que fazem pesquisa, escrevem artigos e livros, participam de congressos, orientam alunos e os que só dão aula e escrevem no quadro-negro. É bem verdade que existem experiências particulares e diferenciadas no seio das universidades públicas federais a esse respeito. São experiências que procuram estabelecer critérios que, de alguma forma, avaliem o que os professores fizeram nesse interstício de 24 meses e a qualidade do que fizeram, como por exemplo, a produção acadêmica, a participação em congressos etc. .... Entretanto, são iniciativas isoladas que não refletem a média do que ocorre no mundo universitário, embora possamos vê-las como expressões concretas de leituras diferenciadas que a questão do desempenho recebe no interior da universidade e a tensão crescente entre elas e o que é normalmente praticado.

Considerando a evidência histórica, apresentada anteriormente, resta-nos perguntar em que medida um novo plano de avaliação dos servidores públicos pode vir a ser, efetivamente, um instrumento poderoso na transformação da meritocracia em uma prática social legítima? Será que alguma coisa mudou no contexto do serviço público brasileiro que indique que este novo plano não sofrerá o mesmo destino dos anteriores? E mais, por que não é difícil estabelecer sistemas meritocráticos formais, embora seja difícil legitimá-los na prática social?

É difícil responder a essas questões de forma cabal. Entretanto, parte das respostas pode ser encontrada nos discursos sobre as razões que levaram às modificações dos diferentes planos de avaliação e nas declarações de funcionários sobre a realidade em que vivem. 
Como mencionado, o primeiro plano de estruturação da carreira do servidor público foi promulgado a partir da Constituição de 1934. Em 1960, foi proposto um novo plano de reestruturação da carreira do servidor público, em substituição ao de 1934. Na época, apontava-se como um de seus objetivos diminuir a margem de arbítrio que a legislação precedente (decreto-lei $\mathrm{n}^{\circ} 284$, de 28 de outubro de 1936) atribuía aos chefes, extinguindo o apadrinhamento de chefes de repartição ou as influências políticas, que acabavam por preterir os funcionários mais qualificados. O critério de classificação dos funcionários por desempenho, adotado pelo boletim de merecimento, descrito como objetivo e impessoal, propunha, também, desafogar os "dirigentes" (Presidente da República, Ministros de Estado e Presidentes de Autarquias), bem como os parlamentares, da avalanche de pedidos que recebiam, nem sempre possíveis de serem atendidos, por se referirem a interesses contraditórios (se atendesse ao A, descontentaria ao B e ao C, e assim por diante). ${ }^{31}$

Em 1977 (decreto-lei no 80.602), um novo plano é proposto e a argumentação adquire um novo matiz. Ao invés de o objetivo ser apenas neutralizar o apadrinhamento e as relações pessoais, a implantação de um novo sistema de avaliação em substituição ao de 1960 objetivava, segundo o diretor do DASP na época, Darcy Siqueira, forçar os chefes a efetivamente avaliarem os seus subordinados e fazer vigorar na prática uma verdadeira meritocracia. Em declaração ao Jornal do Brasil de 25 de outubro de 1977, Darcy Siqueira afirmava que, no serviço público brasileiro, sempre que se solicita opinião dos chefes sobre os funcionários, 99\% deles são considerados acima da média. Para corrigir essa distorção, tinha sido adotada a metodologia da escala de distribuição forçada, que definia, a priori, a percentagem máxima de funcionários que poderia ser considerada de desempenho elevado, médio ou baixo. Além dessa inovação, o novo plano tinha como proposta básica enfatizar as promoções por mérito e extinguir as por tempo de serviço. Segundo o diretor do DASP, no serviço público brasileiro "existe o sujeito com 30 anos de serviço que nunca fez nada e aquele com 10 anos de serviços efetivamente prestados. Então, precisamos medir atributo."

O plano adotado em 1977 durou apenas três anos. Em 1980, ele foi substituído por outro que, ao contrário, voltava a enfatizar a promoção por antigüidade. Desempenho será o critério utilizado apenas para a progressão horizontal (mudança de referência salarial dentro da mesma classe) e a antigüidade para a progressão vertical, independendo do merecimento do servidor, tendo como requisito 
o interstício de doze meses, a escolaridade, a habilitação profissional e a formação especializada, quando necessárias ao exercício da classe a ser provida. Além desses aspectos, era sempre atribuído o conceito 1 (o mais alto existente), independentemente de qualquer avaliação, aos seguintes servidores: ocupantes de cargos de natureza especial, ocupantes de cargos ou funções de direção e assessoramento superior ou intermediário em exercício nos Gabinetes Civil e Militar da Presidência e no Serviço Nacional de Informação; requisitados para o exercício de cargos e funções de direção e assessoramento superior nos Poderes Legislativo e Judiciário da União, do Distrito Federal e Territórios; afastados para cargos de direção superior em empresas públicas, sociedades de economia mista, fundações instituídas pela União e nos serviços dos Estados e Municípios; designados membros de órgãos colegiados federais. Como sabemos que esses cargos são, na sua maioria, ocupados por nomeações e o critério a orientá-las é predominantemente o das relações pessoais, fica claro o peso que ainda hoje é atribuído a essas relações, mesmo que não apareçam como um critério explícito.

$\mathrm{O}$ mais interessante acerca dos motivos invocados para as alterações dos diferentes planos é que eles são os mesmos invocados ainda hoje para justificar a falência do sistema atual de avaliação de desempenho, no serviço público. Em pesquisa realizada entre servidores públicos da administração direta e indireta, num total de 432 questionários respondidos como parte de um projeto de análise cultural de uma empresa estatal, verifiquei que os mesmos dilemas que se encontravam na base das alterações dos antigos planos continuam presentes ainda hoje. Primeiro, quase todos concordam, em tese, que o mérito e o desempenho devem ser os principais, senão os únicos, critérios de avaliação dos funcionários. Portanto, do ponto de vista representacional, as pessoas se colocam como adeptas de uma meritocracia. Segundo, todos estão insatisfeitos com o atual sistema, pois, além de não funcionar - em muitos lugares está suspenso - , muitas pessoas nem sabem que um dia existiu alguma forma de avaliação. O tipo de sistema de avaliação, o processo, a forma como é realizado e os avaliadores, todos são criticados. Terceiro, a desconfiança acerca do sistema é total. Ninguém confia nos resultados. Verifiquei que as pessoas normalmente acham os critérios injustos (79.1\%), assim também como os avaliadores (50.7\%) e, via de regra, os mais bem avaliados são vistos como apadrinhados, "puxasacos" dos chefes etc., mesmo que estas pessoas sejam reconhecidas como bons profissionais e de alto desempenho. Ou seja, quem não recebe uma boa avaliação, via de regra, não legitima a boa avaliação alheia. Quarto, descobri que a antigüidade como um critério de 
ascensão vertical é vista negativamente por $54.8 \%$, um mal necessário na medida em que corrige as injustiças da avaliação de desempenho e, ao mesmo tempo, um incentivo para a acomodação do funcionário, na medida em que, trabalhando ou não, o indivíduo vai ser promovido de qualquer maneira; os outros $46 \%$ consideram que a antigüidade deve ser valorizada. Entretanto, ninguém a quer fora dos sistemas, o que indica, da parte dos 54\%, uma desconfiança em relação aos critérios utilizados. E, por fim mas não menos importante, constatei que os chefes não gostam de avaliar porque isso sempre gera insatisfação entre os funcionários. Como forma de evitar tensões dessa natureza, eles tendem a avaliar todos positivamente.

O que se constata na história dos critérios de ingresso, nos diferentes planos de avaliação de desempenho, nas argumentações utilizadas para justificar as alterações e na pesquisa realizada por mim, entre funcionários da administração direta e indireta, é que, embora esta esteja aparelhada há bastante tempo, do ponto de vista formal, para avaliar e medir o desempenho dos funcionários públicos federais, este processo nunca chegou a ser implementado de forma sistemática, ficando alguns períodos, como aconteceu na década de 1960 e acontece hoje, sem qualquer forma de avaliação.

Neste contexto de alteração de planos, observa-se uma inversão hierárquica: o mérito de valor globalizante nas representações simbólicas passa a valor englobado pela senioridade e pela desconfiança acerca do peso das relações pessoais. Por conseguinte, seria interessante indagar a razão de, na nossa cultura administrativa, mérito e desempenho funcionarem, na prática, como fatores secundários à senioridade e relações pessoais. ${ }^{32}$ Mais ainda, por que num grande número de circunstâncias, quando o mérito é acionado como critério, ele não é legitimado por quem não foi bem avaliado? Como disse uma das minhas entrevistadas, "eu sempre vou achar que é injusta, senão comigo pelo menos com um colega". $\mathrm{O}$ que se constata, aqui, é uma forma de resistência profunda à avaliação, enquanto conceito, princípio, independente dos seus resultados práticos ou possíveis efeitos seletivos, que contrasta fortemente com os discursos sobre a primazia do mérito como valor central das hierarquias administrativas.

A partir do exposto acima, parece-me que a resposta para um melhor entendimento do que está sendo efetivamente dito, nesse debate sobre meritocracia na sociedade brasileira, reside na questão básica: o que as pessoas consideram mérito e desempenho? Qual a explicação dada para as diferenças entre os resultados individuais no desempenho de uma mesma tarefa? 


\section{Igualdade e desempenho}

À primeira vista, pode parecer estranho relacionar a idéia de igualdade à questão da avaliação de desempenho. Igualdade parece ser um valor político mais associado a questões, opiniões e atitudes relativas a eleições, candidatos, governo e ideologias. Na realidade, a idéia de igualdade é muito mais do que um tema político; ela é um valor estrutural nas sociedades modernas, na medida em que se configura como um dos atributos centrais do personagem social característico dessas sociedades - o indivíduo.

Mas, por que igualdade se relaciona com desempenho? Porque, de acordo com a ideologia das sociedades modernas, todos os indivíduos nascem livres e iguais. ${ }^{33}$ Além de sujeitos empíricos, eles também são sujeitos morais. Isso significa que nenhum atributo social do tipo ascendência, riqueza, status, relações pessoais etc. pode ser levado em conta no tratamento que a sociedade dispensa aos seus membros. Eles não definem o indivíduo. O que define o indivíduo é uma suposta semelhança moral dada pela existência de uma dimensão natural/física idêntica entre todos os seres humanos. Essa semelhança de forma é tomada como base de um sistema de direitos ao qual todos devem ter acesso igual. Neste contexto, o único elemento a diferenciar uma pessoa da outra são as características idiossincráticas de cada uma delas, ou seja, tanto os seus talentos naturais como a sua disposição interior para realizar o que os norte-americanos chamam de achievement. E a única hierarquia ideologicamente possível é aquela construída a partir da avaliação dos diferentes desempenhos individuais.

Contudo, para que o desempenho dos indivíduos tenha legitimidade social, ele deve estar inserido num contexto juridicamente igualitário, no qual a igualdade funcione como uma moldura para os acontecimentos e proporcione as condições para que as pessoas sejam avaliadas exclusivamente pelas suas realizações. Ou seja, nenhum outro critério como, por exemplo, poder econômico, status, relações familiares e pessoais pode influenciar esta avaliação. É por isso que desempenho e igualdade estão intimamente associados. Esta última fornece as condições necessárias e suficientes para a sua legitimidade.

Em termos de representações simbólicas, as coisas funcionam mais ou menos como o descrito acima. As variações começam a surgir quando saímos deste nível geral da ideologia e passamos à sua implementação prática em universos sociais distintos. Então, é possível observar-se que os conceitos anteriores - igualdade, desempenho e mérito - embora continuem na base da organização 
social e administrativa das sociedades complexas, possuem

conteúdos sociais distintos, bem como as condições sociais consideradas legítimas para a avaliação das produções individuais.

As implicações dessas variações são básicas para o nosso objetivo pois, se compararmos as concepções sobre igualdade e desempenho desenvolvidas no Brasil e nos Estados Unidos, podemos entender porque, embora possuamos sistemas meritocráticos, estes não possuam legitimidade na nossa prática social. Poderemos constatar, sem muita dificuldade, que o discurso oficial da sociedade norte-americana sobre desempenho e igualdade assemelha-se ao que alguns grupos da sociedade brasileira, particularmente as elites políticas e econômicas e os setores mais individualistas e intelectualizados da população, pensam que deva ser desempenho e igualdade. Esse discurso, contudo, contrasta bastante com a prática social de todos os segmentos da população brasileira que, no momento de aplicar no seu contexto e para si e o seu grupo esses princípios, atribui ao que se entende por desempenho um sentido bastante distinto do norte-americano.

Creio que esses pontos poderão ficar mais claros através de um exercício comparativo entre os significados das categorias igualdade e desempenho para os Estados Unidos e o Brasil.

\section{O significado de igualdade e desempenho nos Estados Unidos}

A igualdade norte-americana é dada pela lei e a ela circunscrita. Traduz-se como direito de acesso igual ao sistema legal e não como uma garantia de sucesso. Concretamente, a concepção de igualdade como um direito significa garantir a todos os indivíduos, independentemente de suas posições na sociedade, de suas desigualdades naturais (sexo, força física, inteligência, desempenho, talentos específicos etc.), um tratamento igual perante a lei, de forma que ninguém seja privilegiado na consecução de seus objetivos e no exercício de seus demais direitos. Portanto, não é intrínseca à idéia de igualdade norte-americana a busca de um estado substantivamente igualitário. A existência da diferença entre os indivíduos é reconhecida, legitimada e percebida como o resultado do diferencial de talento - aptidão inata — que permite a alguns indivíduos realizarem e praticarem certas ações com muito mais eficiência e eficácia - além de desempenho - que outros resultantes da capacidade e desejo de realização (achievement) que cada um possui. Mais ainda, a diferença é positivamente 
valorizada, pois exprime a essência de cada um de nós, enaltecendo o elemento central de todo o sistema social moderno, igualitário e individualista - o indivíduo como personalidade única e irrepetível. As diferenças são assim percebidas como inevitáveis e desejáveis. O que deve ser evitado é qualquer tentativa de usar, do ponto de vista social, qualquer diferença de talento - as chamadas desigualdades naturais do liberalismo - e de desempenho para marcar distinções perante a lei. ${ }^{34}$

A sociedade norte-americana está pronta a admitir a igualdade jurídica - um ideal a ser buscado, de forma permanente, na vida política - e a desigualdade de fato, consequiência das diferenças entre os desempenhos individuais e das desigualdades naturais. A sociedade não coloca como tarefa anular ou aplainar, nem institucional nem juridicamente, essas diferenças. Assim sendo, a idéia de justiça social se aproxima mais de um conceito de proporcionalidade ou eqüidade e menos de igualdade, esta última funcionando, basicamente, como um valor-meio e não um valor-fim..$^{35}$

Neste contexto de igualdade jurídica, o desempenho - como conjunto de aptidões e realizações - funciona como um mecanismo socialmente legítimo, que permite à sociedade diferenciar, avaliar, hierarquizar e premiar os indivíduos entre si. Ele é composto pelo conjunto das realizações objetivas de cada indivíduo, entendidas como o resultado das propriedades idiossincráticas de cada um de nós. Portanto, o desempenho é o resultado de processos e mecanismos intrínsecos ao ser humano, de ordem mais psicológica do que social. Ele é, na perspectiva norte-americana, mais um produto individual do que social. O desempenho é a expressão paradigmática do credo de self-reliance. Ou seja, a capacidade que cada indivíduo tem de perseguir seus objetivos e viver a sua vida baseado em seus próprios recursos.

Neste cenário, desempenho configura-se como a medida que diferencia e atribui valor social aos indivíduos. Conseqüentemente, avaliar se faz necessário pois, só a partir da comparação das diferentes realizações, posso e devo estabelecer hierarquias entre os indivíduos que sejam socialmente legítimas na sociedade norte-americana. Entretanto, como o desempenho é percebido como produto de forças intrínsecas ao ser humano, no momento da avaliação, as circunstâncias sociais, no interior das quais foram produzidas as diferentes realizações, devem ser mantidas constantes. Quero que reconheçam as minhas produções como exclusivamente minhas, o que fui capaz de fazer independentemente de meus determinantes sociais. O que você fez e o que eu fui capaz de fazer, independentemente das circunstâncias em que o fizemos. O que 
está sendo avaliado é resultado contra resultado, individualidade versus individualidade.

Pela lógica do self-reliance, as circunstâncias sociais em que as diferentes individualidades operaram quase nunca são explicitadas ou declinadas a priori para fins de avaliação. Quando aquelas são trazidas à baila, elas o são para valorizar ainda mais o desempenho individual. São utilizadas para comprovar e reforçar ainda mais o valor das realizações, na medida em que comprovam a superação de condições desfavoráveis, que foram revertidas pela força daquela individualidade. É a prova cabal da superioridade ontológica do indivíduo sobre o grupo social. ${ }^{36}$ Por isso que a mobilidade social norte-americana é tão grande e pareceu uma coisa inédita para o olhar europeu de um aristocrata francês como Alex de Tocqueville. ${ }^{37}$ O que parecia impossível em outros universos sociais, parecia factível e comum na sociedade norte-americana. Nela, é possível se ter um curriculum escolar ruim, um emprego medíocre com vinte e dois anos e conseguir reverter toda essa situação através de um bom desempenho, de forma que, através de mudanças sucessivas de emprego para emprego, se chegue a diretor de uma empresa aos quarenta anos. ${ }^{38}$

Não é à toa que o herói norte-americano por excelência é o self made man. Aquele indivíduo que se fez sozinho, sem a ajuda de amigos e parentes, que venceu todas as barreiras baseado apenas em seus méritos pessoais. E este personagem aparece no imaginário norte-americano representando os mais diferentes papéis - cowboy, superman ou um ordinary guy - e nos mais diferentes cenários, mas sempre reproduzindo a mesma história, que é a história da sua luta e quase sempre também da sua vitória. O herói norteamericano é basicamente um sujeito pró-ativo, que age sobre a realidade, transforma-a e molda-a de acordo com a sua visão de mundo. Não tem ajuda de ninguém, a não ser dos inferiores estruturais. Não aceita gratuitamente a realidade ou as imposições do sistema (leia-se sociedade). Por conseguinte, não é à toa, também, que um dos grandes dramas sociais norte-americanos seja a construção de uma identidade social desvinculada de relações pessoais e familiares, baseada apenas na própria trajetória pessoal. Esse drama social se faz presente de várias maneiras nos mais diferentes domínios da vida social norte-americana.

A cinematografia ilustra, com abundância de detalhes, o drama social das pessoas para serem reconhecidas pelos seus próprios méritos, como indivíduos por si mesmos e não como apêndices de outras identidades, como filho de fulano e beltrano. ${ }^{39}$ A própria maneira da apresentação pessoal nos Estados Unidos, quando 
comparada com o mesmo procedimento no Brasil, indica a importância de se ser reconhecido como um indivíduo em si e por si. A pessoa é, via de regra, apresentada pelo seu pré-nome e qualificada pela sua atividade profissional, o que ela faz. Dificilmente há o uso da teknonymy - a identificação de uma pessoa por suas relações de parentesco - como um aposto ao nome pessoal, de maneira a localizar melhor o indivíduo na estrutura social, como fazemos comumente aqui no Brasil, sem causar indignação em quem está sendo apresentado. Isso não quer dizer que, na sociedade brasileira, as pessoas não lutem por criar identidades marcadas por opções próprias e desvinculadas do núcleo familiar, a própria expressão "filhinho de papai" nos sinaliza para a existência de um personagem social, negativamente avaliado em seu comportamento, que se caracteriza por trazer as marcas da trajetória paterna. $\mathrm{O}$ que estou chamando atenção é que este não é um drama central na sociedade brasileira, sua importância restringe-se a um segmento bem marcado do tipo segmento médio, urbano, intelectual, individualista e analisado.

Voltando à problemática norte-americana, a questão do desempenho também aparece nas relações familiares, via criação de uma cultura de self-reliance, na qual, desde a mais tenra infância, as crianças são estimuladas a serem independentes e a marcarem a sua individualidade, através de opções próprias, da independência dos cuidados maternos até a independência econômica e o afastamento físico do núcleo familiar para estudar fora ou trabalhar. No contexto familiar é bem conhecida a comparação entre o comportamento de um pai norte-americano e outro chinês em relação à ajuda recebida do filho na velhice, popularizada por um antropólogo sino-americano, Francis Hsu. Neste exemplo, enquanto um pai norte-americano esconderia esse fato, considerado humilhante por muitos, significando seu fracasso enquanto indivíduo, pois seu desempenho não foi suficientemente bom para provê-lo na velhice, transformando-o em dependente de seu filho, o pai chinês gritaria em altos brados por toda a aldeia a bondade e generosidade de seu filho e a sua sorte de pai.

Uma outra dimensão na qual o significado do desempenho como produto da individualidade aparece com clareza é o permanente debate, nos últimos anos de forma mais candente, sobre o destino da política de cotas nos Estados Unidos. Esta é uma outra instância que ilustra o drama de se legitimar enquanto indivíduo através do desempenho pessoal.

Como é do conhecimento geral, a política de cotas, estabelecida na década de 60 com o objetivo de integrar o negro e 
outras minorias à sociedade norte-americana, via mercado de trabalho e de uma política de discriminação positiva, oferecia condições preferenciais a esses grupos no momento da contratação para um emprego. Em virtude de os empregadores terem a necessidade de preencher, em suas empresas e organizações, determinado número de vagas, as chamadas cotas, estabelecidas em lei, de pessoas oriundas de grupos minoritários, negros, pior qualificados e com menos skills, eram escolhidos em detrimento dos brancos para ocuparem um número determinado de vagas.

Passados quase 30 anos, grupos negros e brancos requerem uma revisão desta política e o conjunto de argumentos utilizados por ambos os grupos ilustra claramente o significado do que é desempenho na sociedade norte-americana. Os negros, que desejam a revogação da política de cotas, alegam que ela, implicitamente, afirma a inferioridade dos negros, na medida em que lhes fornece condições privilegiadas para a obtenção de emprego. Ou seja, o que está sendo dito, indiretamente, através das cotas é que, em igualdade de condições com os brancos, os negros não obteriam os empregos que hoje possuem. Por outro lado, o que os críticos brancos argumentam é que, nos últimos 30 anos, os negros já tiveram a sua oportunidade e se não conseguiram, enquanto grupo, progredir socialmente, agora, o problema é deles. O que não é possível é a permanência de uma política de discriminação das maiorias, no caso o homem branco, um argumento aliás que já foi acolhido em juízo. E o que ambos os grupos estão condenando são as condições privilegiadas dos negros, que colocam o contexto social e histórico no caminho da avaliação, o que impede que a inserção dos negros se dê via desempenho contra desempenho, resultado contra resultado, individualidade contra individualidade.

Mas o que mais exemplifica a concepção do desempenho nos Estados Unidos é o chamado star system. O star system é, justamente, a premiação dos melhores entre os melhores, a consagração do desempenho individual como resultado das características únicas excepcionais de determinados indivíduos. Significa a concessão de privilégios e benefícios muito acima da média, como forma de reconhecimento de um talento e um desempenho considerados excepcionais. É a exaltação máxima da individualidade. O star system aparece com clareza em todos os domínios da vida pública norte-americana: na contratação de professores para as grandes universidades, nas quais ninguém em um mesmo departamento ganha o mesmo salário, pois a remuneração de cada um está ligada às suas publicações e patentes, à capacidade de atrair alunos e investimento para aquelas universidade etc.; na 
contratação de executivos para as grandes empresas onde existem verdadeiros concursos de vantagens para se contratar uma determinada pessoa. Ele ocorre também nos esportes e nas artes, onde aos grandes ídolos são concedidas vantagens excepcionais. ${ }^{40}$

O star system só poderia existir em uma sociedade profundamente impregnada por uma ideologia de meritocracia e por uma concepção de igualdade como um direito e não como um objetivo social. Por outro lado, ele inexiste em uma sociedade como a brasileira, cuja concepção de igualdade dificulta a formação de uma determinada hierarquia meritocrática, neste sentido norte-americano que acabamos de descrever.

\section{O significado de igualdade e desempenho na sociedade brasileira}

No Brasil, as idéias de igualdade e desempenho são concebidas de forma bastante distinta da norte-americana, impossibilitando o estabelecimento de hierarquias que efetivamente se baseiem nas diferenças dos resultados individuais e inviabilizando qualquer coisa semelhante a um star system. Vejamos:

No Brasil, hoje, entendemos igualdade como um conceito duplo. ${ }^{41}$ Ela é um direito e, simultaneamente, um fato. A igualdade de direitos é dada pela lei e a ela circunscrita. Ela se define em relação a um sistema legal e funciona como a explicitação da igualdade de todos perante a lei. A igualdade de fato tem como base um sistema moral mais abrangente, que define a igualdade legal como conjuntural e que considera a igualdade mais do que um direito, define-a como a necessidade de ser, um fato, uma realidade indiscutível. Neste sistema moral, mais importante do que a equivalência jurídica entre os indivíduos é a sua equivalência moral perante uma ordem que se sobrepõe à sociedade. Somos todos iguais, não porque um sistema legal assim nos defina, mas porque, num sistema moral globalizante, a equivalência jurídica aparece como um fato conjuntural que em nada afeta ou modifica nossa equivalência moral como membros da espécie humana. Essa concepção de igualdade, como um fato, tem suas raízes na idéia de que uma mesma condição física e um idêntico e inexorável destino final nos confere um valor - a humanidade, que dá a medida de nossa equivalência. Essa concepção é muito interessante porque, embora usando os mesmos argumentos do liberalismo que sustenta a concepção de igualdade norte-americana para fundamentar a idéia de direitos, a sociedade brasileira chega a um resultado bastante diferente. ${ }^{42}$ 
$\mathrm{O}$ fundamento dos direitos naturais do liberalismo encontrase na semelhança dos homens entre si, enquanto sujeitos morais, seres racionais e fisicamente iguais. Na sociedade norte-americana, como vimos, essa semelhança, dada na natureza, é tomada como base para um direito. Embora a semelhança seja um fato empírico, ela é vista como estritamente formal. Ela não garante um conteúdo idêntico. As desigualdades naturais e de desempenho, estas sim, são consideradas como substantivas, pois delas resultam produtos individuais diferentes, sendo legítimas essas distinções.

No Brasil, o que ocorre é que a semelhança de forma é tomada como base substantiva e irredutível a qualquer outra coisa. As desigualdades que se estabelecem entre os indivíduos são tidas, exclusivamente, como oriundas das condições sociais dos indivíduos e não como conteúdos distintos de uma mesma forma. Portanto, nenhuma legitimidade lhes é atribuída. O esforço de cada um, a vontade de realizar (achievement) e as diferenças de talentos naturais são tidos não como vetores que transformam winners em loosers, como na sociedade norte-americana, mas como resultados inevitáveis e indesejáveis, na medida em que são expressões de processos sobre os quais não temos nenhum controle. O indivíduo, nesta perspectiva, tende a ser percebido como um ser passivo, ao contrário do agente pró-ativo da visão norte-americana, que atua e transforma o ambiente em que vive por força da sua vontade individual.

Devido a essa lógica da igualdade substantiva, o desempenho é entendido mais como o resultado do ambiente e circunstâncias em que os indivíduos operam do que como consequiência dos talentos e de forças intrínsecas ao indivíduo, do tipo esforço, vontade de realizar e talento, ou seja, de mecanismos inatos e psicológicos. Ele é o somatório de duas variáveis externas e uma interna a cada um de nós, que se combinam em proporções diferentes nos indivíduos. São elas:

- a posição social de cada indivíduo (pobre, rico, remediado etc.)

- as deficiências estruturais do sistema brasileiro (o governo não dá dinheiro para a educação, portanto, ele não tinha o livro para estudar, ele é carente, mora longe, não teve oportunidades etc.)

- as minhas idiossincrasias pessoais, subjetivas ( o meu estado de espírito, meu ritmo pessoal, minhas condições familiares e psicológicas etc.).

Devido a essa concepção de desempenho, na sociedade brasileira esperamos sempre que nossas produções individuais sejam avaliadas no contexto em que foram produzidas e cada um de nós atuou. Isso significa que queremos ser analisados dentro da lógica 
do "eu e as minhas circunstâncias". O que eu fui capaz de fazer dentro do contexto social em que operei. Se, na sociedade norteamericana, as circunstâncias são invocadas apenas para valorizar o desempenho individual, na sociedade brasileira elas são sempre lembradas para justificar a qualidade do que cada um foi e é capaz de produzir. A conseqüência disso é que as produções individuais se tornam incomparáveis entre si, pois o produto de cada uma é visto como fruto de condições históricas e subjetivas particulares e únicas, não equivalentes a nenhuma outra, na medida em que, dificilmente, o peso de cada uma das variáveis no desempenho de um indivíduo pode ser medido e, portanto, comparado com o de outro, com as mesmas condições. Por isso é que ou todos são avaliados positivamente ou ninguém é avaliado. Pela mesma lógica, explica-se o sentimento de injustiça que permeia todos os avaliados, quando não recebem uma boa avaliação por parte do superior. $\mathrm{O}$ que implicitamente está sendo apontado é que as suas condições de realização do trabalho e de vida não foram levadas em consideração.

Para a pessoa que avalia e que tem que enquadrar o desempenho de seus subordinados dentro de categorias preestabelecidas as quais não contemplam as variáveis que perfazem o conteúdo da categoria desempenho na sociedade brasileira, o drama é lidar com essa noção implícita de desempenho e com os critérios exigidos pelas avaliações que, via de regra, estão longe de se conformarem a essa lógica. A melhor forma de sintetizar a concepção do que é desempenho para nós é dizer que, no Brasil, desempenho não se avalia, se justifica.

Essa ênfase na justificativa do desempenho, fruto de uma ótica igualitária radical, dificulta a construção de hierarquias baseadas no mérito. E a igualdade de atributo do sistema torna-se o objetivo do próprio sistema, ou seja, a igualdade, enquanto um valor, passa a ser equacionada a um outro: o de justiça social. Almejamos não o desenvolvimento e o reconhecimento dos aspectos idiossincráticos de cada um, mas o estabelecimento de um estado igualitário, onde o que é concedido a um deve ser estendido a todos, independente do desempenho individual e das desigualdades naturais. Daí a síndrome de isonomia, as progressões automáticas para todos e o engessamento do serviço público, no qual diferentes categorias funcionais se encontram amarradas umas às outras, de forma que qualquer diferenciação, mesmo baseada na diferença de funções, é vista como concessão de direitos que devem ser estendidos a todos, o que leva ao famoso efeito cascata. Este não deve ser olhado apenas como um dispositivo jurídico, mas como um dispositivo jurídico que expressa uma dificuldade em se explicitar 
diferenças ao nível simbólico e, acima de tudo, concretizá-las na prática social.

$\mathrm{Na}$ sociedade brasileira, o estabelecimento de gradações ou hierarquias é visto como a introdução de uma desigualdade que vai de encontro ao próprio objetivo do sistema. O único valor com legitimidade a vazar desta perspectiva igualitária radical é a senioridade. E isso faz um extremo sentido. A senioridade está entranhada no código genético e, portanto, é um atributo ao alcance de todos. Já o mérito, resultado do desempenho e das diferenças substantivas individuais, depende do indivíduo e de suas especificidades: nem todos podem tê-lo ou consegui-lo. Por isso, embora os governos, via de regra, suspendam sempre as promoções por mérito a título de economia, mandando uma mensagem clara do status dessa categoria no interior da sociedade brasileira, dificilmente se imiscui com a progressão por antigüidade. Por essa mesma lógica, o único plano de avaliação de desempenho do serviço público federal — o de 1977, mencionado anteriormente, que suspendeu as promoções por antigüidade e estabeleceu as por mérito pelo método da distribuição forçada - durou apenas três anos, sendo substituído por outro que privilegia a senioridade e as relações pessoais e políticas.

Do ponto de vista morfológico, a mobilidade social vertical se dá de forma inteiramente diferente do que ocorre na sociedade norteamericana. No Brasil, do ponto de vista individual, todos se diferenciam a partir do critério de antigüidade ou senioridade, que é o único valor a vazar a nossa ótica igualitária e a introduzir gradações, ou ninguém se move isoladamente pelo desempenho pessoal. Quer dizer, os atributos associados à identidade individual, por mais desenvolvidos que sejam, não são fortes o suficiente para puxar o indivíduo acima da condição igualitária final em direção à qual todos se encaminham. Se permitimos que o critério de senioridade seja o único a vazar o nosso igualitarismo, temos a certeza de que o ideal de igualdade será mantido. O critério de antiguiidade é algo que está ao alcance de todos e pode ser estendido, indiscriminadamente, a todas as categorias. Já o desempenho (mérito) depende dos indivíduos, de suas especificidades, enquanto personalidades e caracteres, e do contexto histórico onde vivem.

Portanto, o que observamos na prática é o movimento vertical de grandes grupos de status e a imobilidade dos indivíduos particulares. Por exemplo, dentro da categoria dos professores universitários temos aqueles que possuem doutorado, mestrado, especialização e graduação. São essas categorias que são diferenciadas entre si e não os indivíduos. No interior delas, vigora a mais radical 
das igualdades, sendo que a única coisa que diferencia um doutor de outro, ou um mestre de outro é justamente o tempo que eles estão na universidade, ou seja os seus respectivos tempos de casa. ${ }^{43}$

$\mathrm{Na}$ administração direta, essa visão também aparece com clareza, no próprio sistema de avaliação de desempenho formalmente em vigor. Embora o sistema distinga entre progressão por mérito e por antigüidade, deixando implícito que o servidor poderia ter uma ou outra, o que ocorre na prática é que, embora o governo diga que os servidores precisam ser avaliados, através do argumento de falta de recursos, ele sempre proíbe a progressão por mérito, permitindo apenas a de antigüidade e, de certa forma, enviando uma mensagem clara do status da idéia de desempenho na sociedade brasileira.

Em um universo como este, a luta pelo reconhecimento do mérito individual é extremamente difícil e polêmica. Difícil porque o sistema público, por decisão política, nega sistematicamente a sua concretização ao proibir as promoções por mérito, embora exercite um discurso inverso e polêmico porque, socialmente, quem clama explicitamente pelo reconhecimento público de suas produções individuais é visto de forma bastante negativa. O reconhecimento público das produções individuais tem que vir junto com uma boa política de relações pessoais. No Brasil, quem quer fazer carreira, de forma ostensiva pelo seu alto desempenho é, via de regra, hostilizado, porque este agente, através de sua trajetória, impõe a todos, no contexto onde se encontra, a explicitação de uma competição baseada em uma concepção de desempenho por produções objetivamente mensuráveis do tipo "eu fiz, eu vendi, eu realizei etc.", que desconhece as variáveis apontadas anteriormente e que gera um ambiente agressivo devido à hierarquia que irá instituir se tiver seu reconhecimento estabelecido. ${ }^{44}$

Num contexto como esse é impossível o estabelecimento de um star system como o norte-americano. A concessão de vantagens e privilégios, como forma de reconhecimento de um desempenho excepcional é bastante conflituosa no interior da sociedade brasileira. O caso de Romário, jogador do Flamengo, é exemplar deste conflito de interpretações sobre o que é desempenho no Brasil. Emprestado pelo Barcelona ao Flamengo por quatro milhões e meio de dólares, no primeiro semestre de 1995, Romário chegou ao Rio nos braços da torcida. Desfilou em carro aberto até a sede do clube e recebeu todos os elogios possíveis e imagináveis da crônica esportiva. Em menos de dois meses, já se havia estabelecido publicamente o debate que nos interessa. Acostumado a ser cobrado pelo seu desempenho individual pelo técnico do Barcelona, Creyfus, ou seja, pelo número de gols e não pelo seu comportamento moral e social, 
Romário foi surpreendido pela reação de parte da torcida e da crônica esportiva. Seu estilo de vida e sua arrogância, ao afirmar que queria ser cobrado pelo seu desempenho em campo e não pelo que ele fazia fora dele, deu início a uma polêmica altamente significativa. Ao não aceitar as mesmas regras de treinamento e concentração impostas aos seus colegas de time, ao afirmar a sua superioridade em relação aos outros e marcar publicamente a sua excelência, ele gerou um forte antagonismo. Em pouco tempo, a lua-de-mel havia acabado, tendo se estabelecido entre o jogador, a crônica esportiva e outros jogadores uma troca de insultos e acusações de falta de profissionalismo. O Flamengo havia alugado uma estrela, que queria um tratamento de estrela, à altura dos talentos de que ela se julgava possuidora. Só que, na sociedade brasileira, tratamento de estrela ostensivamente cobrado, em termos de desempenho individual, é difícil de ser aceito, pois ele estabelece uma hierarquia que o sistema simbólico brasileiro não legitima. Roberto Carlos e Pelé, além de serem ou terem sido excepcionais em suas respectivas áreas de atuação, foram, acima de tudo, estrelas que nunca exigiram, ostensivamente, um tratamento de estrela pelo seu diferencial de desempenho. Sempre procuraram não estabelecer, de cara e de pronto, a diferença entre eles e os demais; preenchem com perfeição o papel de bom moço e não de reis, como a própria sociedade os qualifica.

Por essa mesma lógica é que, no âmbito das universidades federais, nunca se conseguiu estabelecer um sistema que avaliasse o desempenho individual dos professores através de suas publicações. As tentativas de se estabelecer um sistema como este sempre encontraram a maior resistência no meio acadêmico. Os argumentos são os mais variados e vão desde a deslegitimação da publicação como uma forma de avaliar desempenho até a qualidade das revistas. Uma das últimas tentativas nessa área foi feita pelo ex-ministro da Educação, José Goldenberg, que tentou estabelecer um sistema através do qual os professores seriam hierarquizados por suas respectivas produções acadêmicas. Resumidamente, o projeto procurava saber o que cada um dos professores teria produzido nos últimos cinco anos e em que tipo de publicação científica tinham sido publicados os seus resultados. Quando o projeto ainda estava em fase de planejamento, foi jogado na imprensa e bombardeado por todos os lados. O interessante é que qualquer professor universitário sabe exatamente quais são as melhores revistas em sua área, quanto tempo é necessário para se publicar resultados iniciais de pesquisa, quais são os professores que, sistematicamente, estão envolvidos em pesquisa etc., da mesma 
forma que qualquer funcionário público, quando perguntado, sabe responder quem é ou não competente e quem trabalha ou não na sua repartição. Isso, contudo, não significa concordar com o estabelecimento ou a premiação dessas pessoas. No momento desta hierarquização e, principalmente, na distribuição de qualquer tipo de benefício material, esse reconhecimento é neutralizado por argumentos de ordem moral. O tempo de empresa, a dedicação a ela, os serviços prestados no passado, a pontualidade etc., são invocados para justificar o direito às promoções ou a um bom conceito no momento da avaliação de desempenho. Esse tipo de argumentação é sempre mais comum à medida que se desce na hierarquia administrativa. Para os seus segmentos inferiores, os argumentos a favor de uma boa avaliação são quase invariavelmente centrados em argumentos que devem premiar mais o vínculo moral do que o profissional.

Uma outra instância ilustrativa da dificuldade existente, na sociedade brasileira, de se criar hierarquias baseadas no reconhecimento explícito das diferenças nos desempenhos individuais é a Academia Brasileira de Letras. Instituições deste tipo surgem justamente da intenção de premiar publicamente as excelências da sociedade naquela área. Ou seja, o seu objetivo é premiar os melhores naquele setor, concedendo-lhes o título e as honrarias de um acadêmico. É de se supor, portanto, que ali entrem os melhores selecionados justamente pela sua produção literária. No entanto, o mecanismo não é esse. $\mathrm{Na}$ verdade, não se precisa ter nenhum mérito literário para pertencer àquela Casa. Lá se entra por eleição, que é ganha pelo trabalho minucioso feito pelos candidatos de mobilizar, de acordo com a capacidade de cada um, o seu capital de relações pessoais. A eleição funciona como uma forma de neutralizar, do ponto de vista social, o desempenho intelectual e literário dos candidatos, ao colocar em posições substantivamente iguais candidatos com desempenhos altamente diferenciados. Portanto, no interior daquela instituição, encontramos militares, expresidentes, religiosos, médicos famosos, todos com obras literárias desconhecidas, e do lado de fora poetas como Mário Quintana, de obra poética conhecida e apreciada, que jamais foi sequer convidado para o famoso chá das cinco das quintas-feiras.

É claro que esta visão de desempenho não é homogênea, no âmbito da sociedade brasileira. Existem segmentos que advogam, ao nível simbólico, um entendimento de desempenho no sentido norte-americano. Quando as pessoas da administração pública federal, no momento atual e, por exemplo, na década de 1970, falam e falavam da necessidade da construção de uma meritocracia entre 
nós, a concepção entretida é a do mérito, no sentido de algo relativo às produções individuais. Alguns segmentos, principalmente executivos, administradores do setor privado e alguns intelectuais, procuram exercer, na prática, através dos seus sistemas de avaliação, essa concepção. Por exemplo, grande parte do setor privado, principalmente as empresas multinacionais, avalia o mérito gerencial dentro de uma perspectiva de resultado contra resultado. O interessante é que as freqüentes insatisfações são expressas através de argumentos que fazem uso da linguagem e perspectiva da igualdade radical e da justificativa de desempenho porque, embora o discurso seja o de desempenho, que coloca o resultado individual no eixo da responsabilidade de cada um, no momento da aplicação prática a lógica que preside é exatamente a outra.

Mesmo assim, no setor público existem experimentos que procuram fazer avaliações nas quais se contemple o desempenho no sentido de resultados, seja através de sistemas de avaliação cruzada, nos quais uma pessoa é avaliada por várias pessoas diferentes com quem interage profissionalmente, ou através de votação por pontos. Mas o interessante nesses experimentos é que, embora esses sistemas hierarquizem os funcionários entre si em termos da qualidade de seus desempenhos objetivos, no momento da distribuição dos benefícios financeiros, retorna-se à linguagem da igualdade radical. A distribuição se dá igualitariamente e não através da hierarquia de desempenho estabelecida, seja pela avaliação cruzada, seja pela votação por pontos. O argumento é que, normalmente, como o dinheiro disponível é muito pouco, é melhor "dar um pouquinho para cada um para todos receberem alguma coisa."

O importante a marcar é que, mesmo não sendo a única leitura sobre o que é desempenho na sociedade brasileira, a visão dele como um somatório de variáveis que acabam por justificar a qualidade das produções individuais, ao invés de avaliá-las, funciona como um pano de fundo contra o qual se trava o debate sobre o que é desempenho e como avaliá-lo em diferentes grupos na sociedade brasileira. Embora os demais segmentos usem os termos desempenho e mérito para se referirem à necessidade de avaliação e premiação de quem trabalha, a concepção que se tem é a da justificativa de desempenho. Critérios como lealdade, dedicação e pontualidade são invocados, principalmente pelas pessoas que não foram bem avaliadas ou as que ficaram de fora dos possíveis benefícios de uma avaliação, para justificarem o seu próprio desempenho. Neste contexto, enquanto não se explicitar o que cada segmento está realmente dizendo neste debate, de pouco adiantará qualquer novo sistema de avaliação. 
Procurei demonstrar, nas páginas anteriores, que a questão da meritocracia e da avaliação de desempenho, no setor público brasileiro e na sociedade sob um perspectiva mais ampla não é uma questão da existência formal de um sistema que avalie o mérito e o desempenho de seus funcionários. Sistemas que preenchem essa função existem desde o século passado. Centrar esforços apenas nessa direção é se condenar ao mesmo fim de todos os planos e gestões anteriores: a inoperância ou esquecimento.

A questão básica para a mudança de rumos é o entendimento, primeiro da diferença entre sistemas meritocráticos e ideologia da meritocracia e, segundo, dos pressupostos culturais que estão informando implicitamente todo este debate.

O serviço público brasileiro, embora esteja aparelhado sob a forma de um sistema meritocrático, tanto para o ingresso quanto para a mobilidade interna de seus funcionários, não possui uma ideologia de meritocracia, como um valor globalizante e central. Embora, no discurso, todos os segmentos se coloquem como partidários do império do mérito, na prática, qualquer tentativa de implantá-la esbarra em um processo sistemático de desqualificação desse critério, a partir de uma estratégia de acusação que, ora afirma serem o método de avaliação e os avaliadores inaptos para a tarefa, ora terem os escolhidos méritos que, na verdade, não possuem, recebendo uma boa avaliação ou promoção por força de suas relações pessoais.

Sem querer, por um lado, negar a existência de métodos de avaliação anacrônicos, de avaliadores despreparados, do peso das relações pessoais no resultado das avaliações de desempenho, por outro lado, não é possível ignorar concepções culturais básicas que informam, implicitamente, todo esse processo e que, a meu ver, é fundamental serem compreendidas para que seja obtido algum resultado. Refiro-me à existência de uma concepção de igualdade substantiva, que não legitima as diferenças individuais de talento e desempenho como um critério para o estabelecimento de hierarquias, aliada a uma concepção de desempenho que entende os diferentes resultados das produções individuais como oriundos de mecanismos sociais que exigem as suas respectivas contextualizações e explicitações. O resultado disso é um processo que não avalia, no sentido de estabelecer diferenças e hierarquizações, mas que justifica o desempenho. 
A modificação de uma situação como essa é extremamente difícil, na medida em que a alteração de concepções culturais é um processo lento. Por outro lado, é inegável que o estabelecimento de um serviço público mais eficiente, eficaz e de qualidade passa por uma reestruturação desse sistema. Como fazer?

Certamente não será seguindo a tradição da cultura administrativa brasileira, profundamente autoritária, na qual quase todo novo plano de avaliação de desempenho é introduzido como uma maneira de punir, de pôr todo mundo para trabalhar, de separar o joio do trigo. A avaliação nunca foi usada no Brasil como instrumento de crescimento e melhoria do serviço, mas como um instrumento de punição de um corpo de funcionários desmotivados e que nunca foi alvo de uma política sistemática de capacitação e melhora de quadros. Analisando-se a história do treinamento e da educação no Brasil, ninguém fica em dúvida de que ambos são vistos como custos e não como investimento. Portanto, neste momento crucial, no qual se propõe uma reforma do Estado e um novo plano de avaliação por objetivos, espero que se olhe criticamente a experiência histórica brasileira e se aprofunde o debate sobre as nossas lógicas culturais, para que o círculo vicioso que se estabeleceu entre projetos novos e velhos não implementados seja, finalmente, rompido.

\section{Notas}

1 Tecnicamente, funcionário público é aquele que é titular de cargo público. $\mathrm{Na}$ prática, contudo, costuma-se chamar de funcionário público tanto as pessoas que ingressaram por concurso e, conseqüentemente, são titulares de cargo público, como aquelas que entraram no serviço público sem concurso, através de um processo seletivo simplificado e de apadrinhamento político. Para fins desse trabalho, estou considerando funcionário público todas as pessoas que entraram por concurso ou não e que trabalham como contratadas e temporárias, tanto na administração direta como indireta.

${ }^{2}$ Um sistema meritocrático, no serviço público brasileiro, estabelece-se, tanto para o ingresso como para a mobilidade interna, ainda no século XIX. Esse sistema meritocrático tem existência formal, ou seja, pode ser percebido através da reconstrução de uma série diacrônica de leis e decretos referentes ao ingresso no serviço público e à promoção interna das pessoas. A pesquisa dessa legislação é difícil de ser realizada, na medida em que nos órgãos federais não se encontram as informações necessárias disponíveis. Os dados aqui apresentados foram 
recuperados através da bibliografia especializada e da consulta a fontes primárias pela própria autora.

3 Para um panorama introdutório das diferentes escolas de administração ver Chinvenato, I. Administração, Teoria, Processo e Prática. São Paulo: McGraw-Hill, 1985.

${ }^{4}$ Citado a partir de Pimentel, A. F. "A Apuração do Merecimento no Serviço Federal Brasileiro". RSP, ed. DASP, vol. 4, n.2, nov.1953, pp.92-101.

${ }^{5}$ Citado de Pimentel A. F. Opus cit.

${ }^{6}$ Ver Deming, E. As sete doenças fatais da administração.

7 Ver Juran et al. Quality Control Handbook. Mc Graw-Hill Book Company, 1974; Ishikawa, K. Controle de Qualidade Total. Rio de Janeiro: Editora Campus, 1993.

8 Citado a partir de Pimentel, A. F. Opus cit.

9 Citado a partir de Pimentel, A. F. Opus cit.

10 Ver Mc Evoy, G. M. e BeAtTy, R. W. "Assessement centers and subordinates appraisals of managers: a seven-year examination of predictive validity". Personal Psychology, Houston, 42(1): 37-52, Spring 1989; Malvezzi, S. "Habilidades e Avaliação de Executivos". Revista de Administração de Empresas, São Paulo, 31(3): 83-91, jul./set.1991.

11 Ver LegGe, K. Human. Research Management. London: Macmillan Press, 1995.

12 A respeito do bias cultural das teorias de motivação, ver o estimulante artigo de Hofstede, G. "Motivation, leadership and organization: do american theories apply abroad?". Organizational Dynamics, Ed. Amacom, 1980, pp. 42-63.

13 Ver essa seleção de artigos para a visão dos problemas da avaliação de desempenho como centrados na metodologia de aferição e no preparo dos avaliadores: Begamini, C. W. "Novo exame preocupado da avaliação de desempenho". Revista de Administração, vol 18, n.2, abr./jun. 1983, pp.5-11; Carvalho, M.S.M.V. "Análise de desempenho: relatório de análise". In: "Painel sobre avaliação de desempenho". Revista de Administração Pública, Ed. Fundação Getúlio Vargas, vol.13, n.1, jan./mar. pp.105-114; WAHrLich, B. "Contribuição ao estudo da avaliação do desempenho". In: "Painel sobre a avaliação de desempenho". Opus cit.

${ }^{14}$ Para uma descrição detalhada do sistema de avaliação nas empresas japonesas ver Ouchi, W. Theory Z. Reading, Mass., Addison-Wesley, 1981; PAscale, R. E Aтноs, A. G. The Art of Japanese Management, Nova York: Simon \& Schuster, 1981; HaYashi, S. Culture and Management in Japan. Tokyo: Univ. of Tokyo Press, 1988; MARCH, R. Working for a Japanese Company: insights into the multicultural workplace. Tokyo: Kodansha International, 1992.

15 Ver Japan Times. Tokyo, março 1996; DoRE, R. “The Future of Japan Meritocracy”. Bulletin, International House of Japan, n.26, 1970, pp.30-50.

16 Parker, G. M. O Poder das Equipes. Rio de Janeiro: Editora Campus, 1994; Manz, C. C. E e Sims, H. P. Empresas sem Chefes! São Paulo: Makron Books, 1996; Katzenbach, J. R. e Smith, D. K. A força e o Poder das Equipes. São Paulo: Makron Books, 1993.

17 Ver Sansom, G. B. Japan, a short cultural history. London: Barrie \& Jenkins, 1991. Especificamente capítulo XI "The development of chinese institutions on japanese soil".

Ver Gluck, C. Japan's Modern Myths: Ideology in the Late Meiji Period. New Jersey: Ed. Princeton, 1985.

18 Dore, R. P. Education in Tokugawa Japan. Ann Arbor, The Athlone Press, Center for Japanese Studies, The Univeristy of Michigan, 1984. 
${ }^{19}$ Ver Campanhole, A. \& Campanhole, H. L. Todas as Constituições do Brasil. São Paulo: Editora Atlas, 1976.

20 Couto, L. C. A Luta pelo Sistema de Mérito. Petrópolis: Editora Vozes, 1966, RJ. O decreto-lei $n^{\circ} .2549$ de 14 de março de 1860 regulava o concurso e o provimento dos empregos do Tesouro Nacional e da Tesouraria de Fazenda das Províncias e dispunha que o resultado final do concurso seria dado através da votação de esferas brancas e pretas; o decreto-lei ${ }^{\circ} .10340$ de 14 de setembro de 1889 dispunha que o resultado final da prova oral seria dado através da votação por meio de cédulas depositadas em uma urna.

21 O capítulo IV, artigo 92 e 94 dispunha o seguinte em relação ao direito de voto: Art.92 São excluídos de votar nas Assembléias Parochiaes:

I. Os menores de vinte e cinco annos, nos quaes se não comprehendem os casados, e Officiaes Militares, que forem maiores de vinte e um annos, os Bacharéis Formados, e clérigos de Ordens Sacras.

II. Os filhos famílias, que estiverem na companhia de seus pais, salvo se servirem Officios Públicos.

III. Os criados de servir, em cujas classe não entram os Guarda-livros, e primeiros caixeiros das casa de commercio, os Criados da Casa Imperial que não forem de galão branco, e os administradores das fazendas ruraes e fabricas

IV. Os Religiosos, e quaesquer, que vivam em Communidade claustral.

V. Os que não tiverem de renda líquida annual cem mil réis por bens de raiz, industria, commercio, ou empregos.

Art.94 Podem ser Eleitores e votar na eleição dos Deputados, Senadores, e Membros dos Conselhos de Pronvincia todos, os que podem votar na Assembléa Parochial. Exceptuam-se:

I. Os que não tiverem de renda liquida annual duzentos mil réis, por bens de raiz, industria, commercio, ou emprego.

II. Os Libertos.

III. Os criminosos pronunciados em querela ou devassa.

O artigo 96 também excluía do direito ao voto os que não tivessem quatrocentos mil reis de renda líquida, na forma dos arts 92 e 94, os estrangeiros naturalizados e os que não professassem a Religião do Estado. Para as constituições brasileiras ver Campanhole, A. \& Campanhole, H. L. Opus cit. pp.532-533.

22 Ver Campanhole, A. \& Campanhole, H. L. Opus cit. p.476.

23 Ver Campanhole, A. \& Campanhole, H. L. Opus cit. pp.433-434.

24 Citado a partir de Couto, L. C. A Luta pelo Sistema de Mérito. Petrópolis: Editora Vozes, 1966.

25 Ver Campanhole, A. \& Campanhole, H. L. Opus cit.

26 Ver Couto, L.C. Opus cit .

27 Só a título de enriquecimento do que dissemos acima França, Bárbara, no seu livro O barnabé: consciência política do pequeno funcionário público. São Paulo: Editora Cortez, 1993, de uma amostra de 50 pessoas utilizadas na sua pesquisa, $60 \%$ tinham entrado no serviço público por outros meios que não o concurso como enquadramento, tabela especial, cargo comissionado etc.

28 Embora eu tenha pesquisado, não encontrei nenhuma informação acerca da existência de algum sistema de avaliação de desempenho utilizado no período do Brasil monárquico e no início do período republicano.

29 Ver Medeiros, J. Estudos de promoção e acesso. Rio de Janeiro: DASP, 1966. Opus cit., pp.32-33

30 Idem

31 Ver Medeiros, opus cit. 
32 Para a idéia de cultura administrativa ver BARBOSA, L. "Cultura administrativa, uma alternativa ao conceito de cultura organizacional". Rio de Janeiro, 1994, mimeo.

33 Para uma discussão sobre a ideologia moderna ver Dumont, L. Homo Hierarchicus. Paris: Editions Tel, 1967; Dumont, L. Homo Aequalis. Paris: Gallimard, 1977. Para uma discussão sobre modernidade ver GidDEns, A. As consequências da Modernidade. São Paulo: UNESP, 1991; Touraine, A. Crítica da Modernidade, Petrópolis: Editora Vozes, 1994. Para uma discussão sobre ideologia moderna e sociedades igualitárias no contexto da sociedade brasileira ver DaMatta, R. Carnavais, Malandros e Heróis. Rio de Janeiro: Zahar Editores, 1979; Barbosa, L. O Jeitinho Brasileiro ou a Arte de Ser Mais Igual que os Outros. Rio de Janeiro: Editora Campus, 1992.

34 Ver Bobbio, N. A Era dos Direitos. Rio de Janeiro: Campus, 1992; Merquior, J. G. O Liberalismo antigo e moderno. Rio de Janeiro: Nova Fronteira, 1990.

35 Ver BARBosa, L. O Jeitinho Brasileiro ou a Arte de Ser Mais Igual que os Outros. Rio de Janeiro: Editora Campus, 1992; Barbosa, L. e Drummond, J. A. "Os direitos da natureza em uma sociedade relacional; reflexões sobre uma nova ética ambiental". Estudos Históricos. Rio de Janeiro, vol.7, n. 14, 1994.

$36 \mathrm{Um}$ dos temas centrais da administração moderna é o conceito de mudança organizacional e cultural. A forma como a mudança é concebida, dentro do que denomino uma cultura de negócios internacionais, de forte influência norteamericana, na medida que os grandes gurus da administração são norteamericanos, é uma ilustração dessa visão do poder do indivíduo sobre o grupo. Uma das características básicas dessa concepção de mudança, tanto organizacional como cultural, é de que ela é um processo planejado e controlável, no qual a vontade individual desempenha um papel central. A figura de um líder desempenha um papel fundamental neste processo. Sua ação e capacidade de motivar as pessoas é vista como um dos ingredientes de uma mudança bem sucedida. A visão do processo de mudança é tão substantivada que grandes empresas de consultoria do tipo Artur Anderson, MacKinsey etc. não titubeiam em fornecer a seus clientes descrições de mudança organizacional nas quais se encontra uma fórmula de mudança bem sucedida do tipo: MBS $=$. Uma outra fonte interessante sobre esse assunto são os próprios livros de administração que tratam da questão da mudança. Os próprios títulos são sugestivos e indicam a visão como um processo controlável por um ato da vontade individual. Ver, por exemplo, Снамpy, J. Reengenharia da Gerência. Gerenciando a Mudança na Reengenharia. Rio de Janeiro: Editora Campus, 1995; Conner, D. R. Gerenciando na Velocidade da Mudança, como Gerentes Resistentes São Bem Sucedidos e Prosperam Onde Outros Fracassam. Rio de Janeiro: Infobook, 1995, dois grandes sucessos editoriais do momento.

37 Ver Tocqueville, A. Democracy in América. Nova Iorque: Vintage, 1945.

38 Guardadas as devidas proporções, este é o modelo seguido no Brasil no segmento de executivos no qual, através do desempenho, os profissionais vão trocando de emprego, sempre para posições melhores e organizações mais importantes, até atingir o nível de diretoria. O circuito inverso também é verdadeiro. Um desempenho ruim pode levar uma pessoa a fazer todo o caminho contrário. Sair de uma posição boa em uma companhia importante e terminar os dias em uma posição de pouco destaque em uma companhia de médio porte. Aliás, esta circulação de "talentos" é acompanhada de perto e com interesse no mundo dos executivos. Todos sabem quem teve o seu passe comprado por quem e em que condições, quem subiu e quem desceu.

39 Love Story, um sucesso da década de 1970 é um clássico desta temática. 
40 É fundamental se ter em mente que o star, embora receba vantagens maiores que os simples mortais, essas vantagens são o pagamento e o reconhecimento concreto da excepcionalidade de seu desempenho e nada mais do que isso. Não lhe confere direitos diferenciados perante a lei. Aliás, a sua condição de "estrela" o coloca sob um controle social muito maior.

41 Quando falo “no Brasil hoje entendemos...”, estou me referindo a um conjunto de representações que fazem parte do que poderíamos dizer, na ausência de um termo melhor, de uma grande tradição ou de um sistema cultural dominante. Quando também digo grande tradição ou um sistema cultural dominante não estou me referindo unicamente a uma questão de poder, de dominação. Estou me referindo, além disso, aliás, a mais do que isso, à dimensão estrutural desses sistemas, percebida pela sua permanência e expressão em vários domínios da sociedade e pelo seu compartilhamento por vários segmentos. Isso tudo, porém, não significa a exclusão da existência de outras leituras e conteúdos dessa categoria.

${ }^{42}$ Para a questão da igualdade no Brasil ver BARBosa, L. O Jeitinho Brasileiro ou a Arte de Ser Mais Igual Que os Outros. Rio de Janeiro: Editora Campus, terceira impressão, 1995 e Barbosa, L. e Drummond, J. A. "Os diretos da natureza em uma sociedade relacional". Estudos Históricos.

43 Anuênios, biênios, quinquênios são formas de diferenciação através da antigüidade.

44 Em cursos para executivos da administração direta e para empresas privadas, quando as pessoas são perguntadas sobre o que preferem - alto desempenho e um ambiente de trabalho competitivo e um desempenho mais baixo e um ambiente de trabalho mais harmônico, $90 \%$ preferem a segunda hipótese. Esse dado combina com as conclusões de Geertz Hofstede sobre a cultura administrativa brasileira. Em seu mais famoso trabalho, Culture's Consequence, ele indica, a partir de uma pesquisa realizada em 42 países e que durou cerca de oito anos, que no Brasil as pessoas apresentam um baixo índice de atitude de risco.

\section{Referências Bibliográficas}

BARbosa, L. "Cultura administrativa, uma alternativa ao conceito de cultura organizacional”. Rio de Janeiro, 1994, mimeo.

.O Jeitinho Brasileiro ou a Arte de Ser Mais Igual que os Outros. Rio de Janeiro, Editora Campus, 1992.

BARbosa, L. e Drummond, J. A. "Os direitos da natureza numa sociedade relacional". Estudos Históricos. vol. 7, n. 14, 1994.

Bergamini, C. W . "Novo Exame preocupado da avaliação de desempenho". Revista de Administração, vol. 18, n. 2, abr/jun 1983, pp. 5-11.

Bobbio, N. A era dos direitos. Rio de Janeiro: Campus, 1992.

Campanhole, A. \& Campanhole, H. L. Todas as Constituições do Brasil. São Paulo: Editora Atlas, 1976. 
Carvalho, M. S. M. V. “Análise de desempenho: relatório de análise”. In: Painel sobre avaliação de desempenho. Revista de Administração Pública, Editora Fundação Getúlio Vargas, vol. 13, n. 1, jan/mar pp. 105-114.

Снамpy, J. Reengenharia da Gerência, Gerenciando a mudança na reengenharia. Rio de Janeiro: Editora Campus, 1995.

Chiavenato, I. Administração, Teoria, Processo e Prática. São Paulo: McGrawHill, 1985.

CONNER, D.R. Gerenciando na Velocidade da Mudança, como gerentes resilientes são bem sucedidos e prosperam onde outros fracassam. Rio de Janeiro: Infobook, 1995.

Couto, L.C. A Luta pelo Sistema de Mérito. Petrópolis: Editora Vozes, RJ, 1966.

Damatta, R. Carnavais, Malandros e Heróis. Rio de Janeiro: Zahar Editores, 1979.

Dore, R. "The Future of Japan Meritocracy". Bulletin, International House of Japan, n. 26, 1970, pp. 30-50.

. Education in Tokugawa Japan. Ann Arbor, The Athlone Press,

Center for Japanese Studies. The University of Michigan, 1984.

Dumont, L. Homo Hierarchicus. Paris: Editions Tel, 1967.

Homo Aequalis. Paris: Gallimard, 1977.

FrançA, B. O Barnabé: consciência política do pequeno funcionário público. São Paulo, Editora Cortez, 1993.

GidDEns, A. As conseqüências da Modernidade. São Paulo: UNESP, 1991.

GLuck, C. Japan's Modern Myths: ideology in the Late Meiji Period. New Jersey: Ed. Princeton, 1985.

Hayashi, S. Culture and Management in Japan. Tokyo: University of Tokyo Press, 1988.

Hofstede, G. "Motivation, leadership and organization: do american theories apply abroad?" Organization Dynamics, Ed. Amacom, 1980, pp. 42-63.

Ishikawa, K. Controle de Qualidade Total. Rio de Janeiro: Editora Campus, 1993.

Katzenbach, J.R. e Smith. D.K. A força e o Poder das Equipes. São Paulo: Makron Books, 1993.

JaPAN Times. Tokyo, março de 1996.

JURAN et alli. Quality Control Handbook. McGraw-Hill Book Company, 1974.

LegGe, K. Human Research Management. London: Macmillan Press, 1995.

Malvezzı, S. "Habilidades e Avaliação de Executivos". Revista de Administração de Empresas, São Paulo, 31(3): 83-91 - jul/set 1991.

Manz, C. C. e Sims, H. P. Empresas sem Chefes! São Paulo: Makron Books, 1996.

MARCH, R. Working for a Japanese Company: insights into the multicultural workplace. Tokyo: Kodansha International, 1992.

Mc evoy, G. M. e Beatty, R. W. "Assessment centers and subordinates appraisals of managers: a seven-year examination of predictive validity". Personal Psychology, Houston, 42(1): 37-52, spring 1989.

Medeiros, J. Estudos de promoção e acesso. Rio de Janeiro: DASPm 1966, pp. 32 e 33.

Merquior, J. G. O Liberalismo antigo e moderno. Rio de Janeiro: Nova Fronteira, 1990.

OuchI, W. "Theory Z”. Reading, Mass., Addison-Wesley, 1981.

PARKer, G. M. O Poder das Equipes. Rio de Janeiro: Editora Campus, 1994.

Pascale, R. e Athos, A.G. The Art of Japanese Management, Nova York: Simon \& Schuster, 1981.

Pimentel, A. F. A "Apuração do Merecimento no Serviço Federal Brasileiro". Revista do Serviço Público, ed. DASP, vol. 4, nov. 1953, pp. 92-101.

SAnsom, G. B. Japan, a short cultural history. London: Barrie \& Jenkins, 1991. 
Tocqueville, A. Democracy in America. New York: Vintage, 1945.

Touraine, A. Crítica da Modernidade, Petrópolis: Editora Vozes, 1994.

WAHrLICH, B. "Contribuição ao estudo da avaliação do desempenho". In: Painel sobre a avaliação de desempenho. Revista de Administração Pública vol. $13 \mathrm{n}$. 1, Fundação Getúlio Vargas jan/mar pp. 105-114. 
Meritocracia à brasileira: o que é desempenho no Brasil?

Lívia Barbosa

O artigo trata da questão da meritocracia e da avaliação de desempenho no setor público brasileiro e na sociedade sob uma perspectiva mais ampla, enfatizando a diferença entre a existência de sistemas meritocráticos formais e sua legitimidade social. Para a autora, o cerne desta discussão passa pelo entendimento da diferença entre sistemas meritocráticos e ideologia da meritocracia e pela compreensão dos pressupostos culturais que estão informando este debate. $\mathrm{O}$ artigo situa a questão da meritocracia em contextos mais amplos, como a teoria da administração, a perspectiva intercultural e a ótica históricosociológica, sem perder de vista as especificidades da sociedade brasileira.

\section{Meritocracia a la brasileña: ¿ qué es el desempeño en Brasil? \\ Livia Barbosa}

El artículo trata de la cuestión de la meritocracia y de la evaluación del desempeño en el sector público brasileño y en la sociedad bajo una perspectiva más amplia, haciendo hincapié en la diferencia entre la existencia de sistemas meritocráticos formales y su legitimidad social. Para la autora, el cierne de esta discusión es la comprensión de la diferencia entre sistemas meritocráticos y la ideología de la meritocracia y la comprensión de los fundamentos culturales que están informando este debate. El artículo sitúa la cuestión de la meritocracia en contextos más amplios, tales como la teoría de la administración, la perspectiva intercultural y la óptica histórico-sociológica, sin perder de vista las especificidades de la sociedad brasileña.

\section{Merit-based bureaucracy, Brazilian style: What is perfomance in Brazil? Lívia Barbosa}

The article deals with the issue of merit-based bureaucracy and of performance evaluation in the Brazilian public sector and in society through a wider focus, stressing the difference between the existence of formal merit-based systems and its social legitimacy. According to the author, the central point of this discussion has to take into account the understanding of the difference between merit-based systems and the ideology of merit-based bureaucracy, and the understanding of the cultural assumptions that inform this discussion. The article places the issue of merit-based bureaucracy in wider contexts, such as the administrative theory, the intellectual perspective, the historical-sociological angle, without loosing sight of the characteristics of the Brazilian society. 